Article

\title{
Innovation Adoption: Empirical Analysis on the Example of Selected Factors of Organizational Culture in the IT Industry in Poland
}

\author{
Józef Ober(D) \\ Department of Applied Social Sciences, Faculty of Organization and Management, Silesian University \\ of Technology, Roosevelta 26-28, 41-800 Zabrze, Poland; Jozef.Ober@polsl.pl; Tel.: +48-32-277-7323
}

Received: 3 September 2020; Accepted: 16 October 2020; Published: 18 October 2020

\begin{abstract}
Positive adoption of innovation by staff is a current and crucial issue for proper operation of businesses, industry, and socio-economic environment. The article discusses variables affecting innovation adoption and analyses selected organisational culture factors in terms of their impact on innovation adoption in Polish IT companies. A novelty here is a study of their impact separately at each stage of innovation. The objective was to assess the perception of the impact of selected organisational culture factors on adoption of innovation by Polish IT industry staff at different stages. Due to the complexity of the different research aspects, a method triangulation strategy was used, combining survey techniques, desk research, expert opinions and statistical analysis. The survey used an original questionnaire called "The Process of Innovation Adoption and Perception" to examine opinions on 15 organisational culture factors in the context of innovation adoption. The research confirmed that selected organisational culture factors have a different impact on innovation adoption at different stages of innovation introduction in the Polish IT industry. On this basis, groups of factors perceived similarly in terms of innovation adoption at the individual stages were identified, forming guidelines for the proper implementation of innovation in Polish IT companies.
\end{abstract}

Keywords: innovation adoption; innovations; innovativeness; organisational culture

\section{Introduction}

In order for companies to develop and stay on the market, they need new ideas and innovative solutions. Otherwise, there is a danger of stagnation, worsening of the company's competitive position or even failure. The issue of innovation adoption is still current due to its significance for socio-economic development [1,2] and industrial competitiveness [3]. Furthermore, positive adoption of innovation by employees contributes to a more cohesive organisational culture, thus influencing employee integration and increasing the level of trust between them [4]. Recent research also confirms that positive adoption of innovation by employees helps organisations overcome performance shortfalls and seize new opportunities within and around the company [5]. The above aspects are very important from the point of view of sustainable development and considerations on the needs and relationships between society 5.0 and industry 4.0. Transformation of companies towards industry 4.0 nowadays means not only transformation of a few companies, but also an opportunity to survive difficult and turbulent periods on the market, including the organisational and economic shock caused by the COVID-19 pandemic, and to find one's place in the post-pandemic period both from the point of view of companies and society as a whole. That is why it seems so important to pay attention to issues connected to innovation adoption, which are researched all over the world, resulting in extensive but very fragmented literature [6]. The aim of this study is to assess the perception of the 
impact of selected organisational culture factors on adoption of innovation by Polish IT industry staff at different stages.

The issue of innovation in source literature is presented very differently, from many perspectives and points of view, and the number of definitions is vast. Recent approaches to innovation stress that it is a deliberate and organised action by entrepreneurs to achieve a specific economic objective, to meet market needs more accurately and to make reasonable use of available or obtainable resources [7]. According to a different interpretation, innovation is the result of the progress of knowledge and invention, i.e., it is an innovative discovery that is used in the field of production and leads to new products [8]. This trend also includes a definition by Agnieszka Sopińska and Wioletta Mierzejewska [9], who state that innovation is a change in production methods, products and organisation of the production process based on new or previously unused knowledge. The idea of innovation must be separated from the term innovativeness. The two terms are interchangeable in the literature but have different meanings. Innovativeness can be explained as the company's ability and potential to find, adapt and further develop new and improved products, services and technologies $[10,11]$ and as an ability to share the company's resources in such a way as to ensure the best competitive advantage within a given period of time $[12,13]$. It can also be noted that innovativeness is often associated with creativity. The main and most fundamental difference is the conclusion that innovation is the culmination of creative thinking in the form of innovative ideas being put into practice by an organisation [14].

In recent years, there have been many studies on the characteristics of organisations that strengthen or hinder the introduction of innovation, the impact of informal communication on the innovation process [15] and the conditions under which innovative projects are later introduced [16]. Despite a number of theoretical and practical studies on the impact of organisational characteristics on innovation, it has not been possible to establish a unified position on the role of variables that may influence adaptation of innovation positively or negatively [17]. Based on the results of these studies, the most important organisational characteristics that determine the success of innovation adoption were identified. These are: Vertical integration, which can both facilitate and hinder technological innovation; size of the organisation; openness to new solutions; product diversity.

The structure of the remaining part of the article begins with a review of literature on adoption of innovation, in particular of different approaches to the role of organisational variables and other factors influencing adoption of innovation. This is followed by a description of the methodology used in this study and the results of the analysis and discussion. Finally, conclusions from a scientific point of view are presented, as well as practical management tips and suggestions for further research.

\section{Literature Review}

An analysis of the available literature on organisational innovation has shown that organisational variables and contextual and individual factors have a decisive role in the adoption of innovation. The already-mentioned research by Fariborz Danampour [17] indicates the type of organisation as a critical value, especially at the stage of innovation adaptation. Empirical research [18] has confirmed that it is the size of the organisation that mainly influences adoption of innovation. In one view, it was negative, in others, definitely positive [19]. Some researchers have also linked the degree of diversification to organisational innovation by examining the economies of scope [20], the need to gain a competitive advantage [21] and difficulties with introducing innovation [22]. Factors extremely important for an organisation in the process of planning adoption of innovation are the resources and possibility to use innovation to increase the company's income [17]. The company's own or external source of financing and the method of distribution of its products may also have a decisive impact on whether a decision to introduce innovation will be made [23] and on the time of its introduction and the pace of the whole process [24].

Innovation theorists, conducting research on organisational boundaries and innovation, disagree on the impact of horizontal and vertical integration on innovation adaptation [25]. From the 
point of view of information processing, internalisation of technological input or product distribution can reduce production costs and simplify sequential coordination of the different steps of production that are necessary to adopt innovation [26]. However, use of the market and external technologies, instead of internal mechanisms, may accelerate adaptation of new technologies [27]. Reverse integration definitely slows down adoption of innovation, allows for better control over expenditures and affects the competitive position of the organisation [28]. In this type of integration, adaptation of innovation, especially in highly technological industries, can be very costly, as it requires large expenditures on technologies, both financial and organisational [29]. Particular attention should be paid to situations in which retroactive integration may not be favourable to the long-term interests of the company if the technology changes frequently and consumes large, permanent investments [30]. In turn, when retroactive integration is applied to investments made with outdated technologies, the likelihood of adopting innovation is reduced. A different concept was presented by researchers Kirk Monteverde and David J. Teece [31], who noted that retroactive integration of a company can redirect issues related to external supply inside the company, which can make it easier for the company to coordinate activities between internal branches, rather than between independent companies. In turn, Amar Gupta and Hoo-Min D. Toong [32] note that companies using internal integration are more likely to potentially increase their competitive advantage and use new technologies in their own operations. Moreover, with this type of integration, common ownership of key elements results in a significant reduction of institutional barriers and coordination costs of the innovation process [33]. By looking at technological innovations in this way, one can primarily see the benefits for the company itself, and the impact on accelerating their introduction. Another element influencing decisions to adapt innovations is the use of one's own product distribution channel [19].

As in the case of retroactive integration, the views of researchers on the impact of forward innovation on innovation adoption are divided. Some believe that it slows down the adaptation process, while others claim that it accelerates it. Among the supporters of the latter position are Erin Anderson and David C. Schmittlein [34], for whom forward integration leads to acceleration of the adoption of innovation, because by controlling internal distribution, the organisation also controls the introduction of new solutions to its customers. Researchers also see another advantage, namely that a company can better train and educate its salespeople in the benefits of innovation and the use of new technologies, offering them specific rewards and incentives to motivate them to sell these new products. Moreover, by controlling distribution channels, it is easier to ensure shelf space for a new product [35]. Also, in such a situation, pressure from the sales and distribution department, which sees a real opportunity to increase revenues and effectively compete against competition by offering products with the latest technologies, may be a factor accelerating the decision to adapt innovation.

The opposite position is presented by researchers who claim that forward adaptation slows down and limits the process of introducing innovation. They believe that the main obstacles, among others, include lack of knowledge of new technologies among vendors, and thus their scepticism about innovative solutions and concerns about customers' reluctance to accept new solutions [36]. There is also uncertainty about the introduction of innovative solutions and the belief that modernisation of a product or service may reduce the stability of their position on the market [37], and thus give competitors an advantage in this respect [38]. Independent distributors may also have doubts. On one hand, they will see the potential of advanced technology [33] and will therefore be more willing to sell such products or services, even taking into account small costs of possible complaints.

Another factor analysed from the point of view of introducing innovations is the size of the organisation [17]. There is no consensus among researchers as to whether this factor contributes to a positive or negative attitude to innovation adaptation [39]. One of the examined elements is formalisation and decentralisation of organisations, which usually represent completely contradictory values and have a completely different impact on the adoption of innovation. One of the arguments indicating that a larger organisation will innovate more quickly is that it has more resources and a better ability to compete [40]. In addition, larger organisations have a greater tendency to make mistakes and 
take risks. Due to their size, economies will also be more favourable to larger companies, which may also be an argument in favour of the innovation adoption [41]. A stronger tendency to adopt innovation may also result from a top-down assessment of the market situation by large enterprises [42].

On the other hand, the size of an organisation may be associated with values that slow down and block adaptation of innovation due to extensive bureaucracy and adoption of new technologies on a large scale [43]. Research conducted by Henry Mintzberg and Jerald Hage [44] has shown that in small organisations, it is easier to achieve coordination between different departments within the company than in a highly structured organisation. Whereas analyses carried out by Louis G. Tornatzky and Katherine J. Klein [45] indicate that it may be easier for smaller organisations to reach out to their clients with a new solution thanks to the ability to act fast on the market, without extensive procedural constraints. This relationship was also noted by Edwin Mansfield [46], who stated that small companies are more likely to be among the first to apply innovation.

Product diversity is a decisive element in terms of the speed of innovation. If there are a lot of products, there is a threat of slowing down the process of introducing novelties. The situation is similar when an extremely difficult technology is used to manufacture products [22]. A similar situation occurs when a company offers a very wide range of products, designed for a diverse group of customers with different expectations and needs. The feedback provided by these users on the novelties may be inconsistent or even completely contradictory and thus delay the adaptation process [47]. Robert E. Hoskisson, Michael A. Hitt and R. Duane Ireland [48] have examined the issue of innovation from yet another perspective. They looked at the problem from the point of view of increasing product diversity and the growing risk, especially for managers, which makes persons in managerial positions resistant and reluctant to point to new products.

From the point of view of economists, an important argument for diversification is the use of the company's specific character on various markets [49]. Such a specific character of the company reflects the organisation's willingness to implement a competitive strategy, which consists of an early market entry with new products [50]. In such a situation, companies need to make quick and basic choices between high diversity and effectiveness of the chosen strategy. However, researchers note that companies focusing on a narrow range of products are much more efficient on the market, while companies with a strongly diversified offering try to be more innovative [21]. Praveen R. Nayyar [20] concluded that it is the economies of scope that are the main benefit of diversification and can lead to higher levels of innovation. Based on these contradictory arguments about the consequences of product diversity, this issue can be considered open and left for further theoretical and practical analysis.

Most literary sources focus on an analysis of technological innovations [51], however, as can be seen from the results of multidisciplinary research, more and more importance is being attached to the role of innovation in managing an organisation [52], i.e., its impact on management innovation (MI) [53]. The factors that positively affect MI include leadership behaviour, organisational learning and size of the organisation [54]. Unfortunately, research conducted on this issue leads to contradictory conclusions for several variables determining adoption of innovation, namely the size of the organisation and its financial results. Some researchers, for example Goudarz Azar and Francesco Ciabuschi [55], Erik G. Hansen [56] and Julia Nieves [57] see a positive relationship between the size of the organisation and a positive attitude to innovation in management. Whereas Mi Zhou, Louis C. Vaccaro, Wei Qi [58] and Matej Černe, Marko Jaklič, Micha Škerlavaj [59] find no connection between these two parameters.

The elements mentioned above lead to an increase in the profitability of the company by increasing the demand for the product or a significant reduction in production costs. They also result in accumulation of knowledge in the company and increase the competence of employees $[60,61]$. The lack of unambiguous results of the research on these indicators makes it impossible to establish an unambiguous thesis about their positive impact on the organisation and management practices [62]. As is known, innovation has been studied in many academic disciplines, including business administration, public management and sociology, using different methods and levels 
of analysis [63]. One of the classifications on which most researchers agree is technological and non-technological innovation [64]. Non-technological innovations have been classed as MI and administrative innovations by researchers such as: Julian Birkinshaw, Gary Hamel, Michael J. Mol [65] and Sascha Kraus, Mikko Pohjola, Aki Koponen [66]. These two types of innovations overlap to a significant extent and differ significantly from product, technological and process innovations [17].

The main difference between innovation in management and technological innovation lies primarily in the result of each of them. Technological innovations are dominated by process or product development and can be more easily defined [67]. On the other hand, administrative innovation is much more complicated and complex [68] and contributes to longer durability and competitive advantage on the market, which is difficult to imitate for other companies [69]. The definition of non-technological, administrative and managerial innovations by Fariborz Damanpour and Deepa Aravind [64] can be quoted here, which states that it is a completely new approach to the tasks of the company's management and that it includes all new processes that lead to changes in the organisation, its strategy, structure and administrative processes and systems. Analysis of the issue of innovation adoption and the factors influencing this process leads to many, often contradictory conclusions. This is undoubtedly a complex and multidimensional process, which is why it is examined in many areas and the conclusions often go beyond the process of innovation adaptation itself.

Innovation is considered to be one of the most important and stable beginnings of long-term success of an organisation $[70,71]$. Challenges faced by organizations in today's world and market concern not only offering innovative products and solutions, but also change the nature of management in organisations towards improving productivity, customer service and performance [64,72,73]. Recent research shows that managers should be extremely careful when introducing innovation. Particularly when companies represent advanced technologies, the role of the manager is especially important as the person who will properly present the function of such an innovation in order to gain acceptance of employees [5]. These studies confirm the assumptions of this paper that the human factor is one of the most important and often overlooked conditions for positive adoption of innovation. Most research on innovation adoption is seen as a single stage, examining whether it has been adopted and to what extent [74]. There are, of course, approaches that consider innovation as a process consisting of several phases. Not many researchers distinguish two phases: The initiation phase and the innovation implementation phase [75]. The first one requires generation of a new and useful idea, which can be adopted in the second phase. In this approach, authors [75] pay particular attention to the role of organisational and national culture as factors influencing the effectiveness of innovation implementation. By far the most common literature divides the innovation process into three stages. The most recent interpretation distinguishes between pre-adoption, adoption and post-adoption stages [4]. While analysing source literature one can see that the three stages are most commonly used in science, but they take different names and definitions. These considerations are based on the concept of division of the stages of innovation by Mumtaz Abdul Hameed, Steve Counsell and Stephen Swift [76] into initiation, decision to adopt innovation and implementation of innovation. The first stage, i.e., initiation, otherwise known as pre-adaptation, describes all the periods preceding and preparing for the implementation of innovation. It therefore includes activities such as: Identifying a need, finding a solution, gaining knowledge about existing innovations, preparing preliminary opinions on innovation and preparing it for implementation. The second stage, i.e., the decision to adopt innovation, is the decision of the management as to whether it should be implemented. This concerns the decision to accept the proposed idea and assessment of the desired solution in practical, strategic, financial and technological terms [77]. The researchers found that at this stage, organisational characteristics and managerial attitudes to innovation have a much greater impact on its adoption than demographic and environmental characteristics [76]. At this stage, top managers broaden the perception of innovation by deciding whether it will support the development of organisational and company goals. The third and final stage is implementation, i.e., all post-adoption activities consisting in modifying the innovation, preparing the organisation for general application of the innovation and carrying out attempts to 
confirm acceptance of the innovation in the organisation and by employees [78]. As can be seen from the above considerations, each stage of innovation is characterised by different conditions, which justifies the idea of treating them separately in the research on innovation adoption. It is worth noting here that despite the consensus on the division of the innovation process into stages, the studies presented in literature mainly concern factors that have an aggregate effect on the whole process [74]. Therefore, from the point of view of the theory and practice of innovation adoption, research that distinguishes between different factors at different stages of innovation is most relevant. It is important to analyse each stage of innovation separately in terms of the factors that may potentially encourage its adoption. It is worth noting that identification of factors that have a positive impact on adoption of innovation can be both a driver for the adoption of innovation and a barrier in case of absence of innovation in a given company [79].

While analysing literature, the influence of organisational culture and cultural values on the adoption of innovation was noted [80,81]. These studies have shown a link between certain elements of the organisational culture, such as values, beliefs and attitudes, work practices and behaviours [81]. However, they relate to the innovation process as a whole, without analysing the individual stages. From a cognitive perspective, organisational culture is a system of shared discoveries or a system of knowledge and beliefs. In this approach, it is assumed that thought is directly linked to action. When analysing the concept of culture from a symbolic point of view, it can be treated as a system of common symbols and meanings [82]. For the purpose of this study organisational culture factors, which are potentially conducive to adoption of innovation at different stages of implementation, have been identified on the basis of literature analysis, pilot studies and expert assessment. The following factors were distinguished:

- Giving employees an opportunity to challenge existing solutions [82], i.e., creating a new perspective on existing solutions;

- Ergonomics of workstations [83], i.e., ensuring comfortable and safe workstations, which may result in an increased sense of overall employee safety;

- Creation by the company of favourable conditions for development of employees' competences [84] such behaviour makes it possible to ensure that the qualifications of employed staff remain current and that the knowledge is always up to date;

- Ensuring employees' independence [83], i.e., supporting and promoting individualism and prioritising the good of the individual over the good of the social group;

- Sense of co-ownership and control over one's own work [85], which may increase employee motivation and involvement and encourage innovative action;

- Encouraging employees to continue learning [84]—it has a positive impact on the development of employees, which may result in new ideas and solutions;

- Freedom to experiment and take risks at work [86], which is a kind of testing ground for employees who learn how to manage risk on a microscale;

- Exchanging knowledge between different company departments [78]—in this process, managers in particular should be responsible for ensuring smooth flow of data, information and knowledge;

- Shared commitments with regard to implementing a specific project [86]—a sense of community can foster integration;

- Promotion by managers of the value of dialogue, cooperation and partnership [87] —it is extremely important for the organisational culture and implementation of innovation to share knowledge, successes and failures from which constructive conclusions can be drawn for the team;

- Encouraging staff to discuss each other's ideas [87]—discussion and formulation of opinions can have constructive effects on the development of the whole company and adoption of innovation;

- Regular brainstorming [88] making it possible to meet diverse participants (in terms of age, gender, experience in a given field), who will try to solve a given problem under the supervision of a moderator; 
- Openness to new solutions and flexibility in solving problems [89]—all doubts and problems should be solved and analysed together. Such an organisational culture is conducive to meeting the needs for respect and recognition, and allows subordinates to plan independently and achieve their own goals;

- Mutual trust within the team/organisation [90]—it is one of the most important elements of the organisational culture. If employees act in harmony and trust each other, they are able to meet any arising challenges;

- Proper recognition and incentives for employees [89] — this factor may determine the results of work and openness to innovation.

The above considerations encouraged the author to put forward the following hypothesis: Selected factors of organisational culture affect adoption of innovation differently at different stages of innovation introduction process.

\section{Materials and Methods}

The research problem presented in this paper is the behaviour of IT industry employees in Poland towards the process of innovation. For the purpose of this article, factors related to the company's organisational culture that can potentially affect the adoption of innovation have been identified. It is worth noting that despite the division of the process of innovation introduction into different stages, in their analyses, most researchers generalise the impact of factors influencing adoption of innovation for the whole process of its introduction, without taking into account differences at the aforementioned stages [91]. This approach assumes that the factors related to company organisational culture used in the questionnaire have a different impact on the adoption of innovation at different stages of the process, which became the basis for empirical research.

The IT industry was selected for this research because it is becoming an opportunity for Poland to increase its competitive advantage on global markets. The present time has become known as the information technology era. It is the key driver of economic growth, not only for each nation, but for the whole world. It plays such an important role because it relates not only to professional life, but to each tiny part of private and everyday life, where it can be seen everywhere and without which it would be difficult to imagine the functioning of the modern world. From the global perspective, the Polish IT market has been very competitive for many years. It keeps up with all the novelties in this field, and above all, it develops and modernises them all the time. The IT industry is one of the few industries in Poland that does not lag behind the world leaders [92].

The objective of the research was to identify and assess the perception of the impact of selected factors related to company organisational culture in terms of adoption of innovation by IT industry staff in Poland at different stages of the process of its introduction. The paper adopted the following hypothesis: Selected factors of organisational culture affect adoption of innovation differently at different stages of innovation introduction process. In other words, it was assumed that the influence of individual organisational culture factors on adoption of innovation varies in importance, depending on the given factor and on the specific stage of innovation implementation.

Due to the complexity of research aspects, it was decided to apply the strategy of method triangulation, which, according to Wojciech Czakon [93], consists of combining different research methods in one study and then comparing and combining research results. According to Monika Kostera [94], the use of two or more research methods, on the basis of which it is possible to compare the obtained results and draw conclusions, makes the study more reliable, while Henryk Dźwigot [95] emphasizes that method triangulation makes it possible to analyse reality from many perspectives. For the purpose of this study, it was decided to combine survey techniques, desk research and expert opinions in a method triangulation procedure. The study used a proprietary questionnaire, entitled "The Process of Innovation Adoption and Perception", developed specifically for the purpose of this study. This tool made it possible to examine the respondents' opinions on 15 factors related to company organisational culture in the context of adopting innovation. These factors were selected 
for the questionnaire on the basis of literature research, desk research, opinions of panel participants (experts) and pilot studies conducted at IT companies in Poland in the period from early September to late December 2018.

The respondents referred to particular behaviours related to the company's organisational culture and assessed their potential impact on adoption of innovation in the context of the individual stages of the innovation implementation process. Their task was to estimate with the use of a 5-point Likert scale (1-definitely negative, 2-rather negative, 3-neither negative nor positive, 4 -rather positive, 5-definitively positive) the potential impact of individual factors on adoption of innovation, combined with an additional point indicating a total lack of the abovementioned impact (0-no impact on adoption of innovation). What was important and innovative in the field of management and quality sciences, the above-mentioned impact or lack of it was determined separately in relation to the three stages of the innovation implementation process: The innovation initiation stage, the decision to adopt innovation stage, the innovation implementation stage.

In order to determine the reliability of the "The Process of Innovation Adoption and Perception" questionnaire, Cronbach's alpha internal consistency coefficients were calculated for a group of organisational culture factors. They turned out to be very reliable at each stage: Innovation initiation stage: Alpha $=0.88$; decision on adopting innovation stage: Alpha $=0.87$; innovation implementation stage: Alpha $=0.86$. A detailed distribution of factors and variables is shown in Table A1 (Appendix A). Statistical analysis was aimed at assessing the various factors of organisational culture in terms of their impact on the adoption of innovation at different stages of the innovation introduction process. In other words, the aim of the analysis was to identify the factors whose application at different stages of the innovation introduction process is most significant for its final adoption. The study compares the individual stages of the innovation introduction process in terms of: Seeing any impact of the individual factors on adoption of innovation; assessment of the form of that impact (on a scale of 1-5) on adoption of innovation (if impact of a given factor is seen); average assessment of the form of that impact on adoption of innovation of organisational culture factors.

Before commencing the analysis, the database was verified in terms of the logic and completeness of responses. In order to select appropriate statistical tests to examine the relationships, it was verified that all the necessary objectives allowing the use of the individual statistical tests have been met, i.e., normal distribution verified using the Shapiro-Wilk test; appropriate sample size; variables on an appropriate scale (quantitative or qualitative); randomness of samples taken (independence of tested groups from each other). The verification of the above-mentioned objectives indicated that the data do not meet the condition of normal distribution, neither in general nor within the examined groups. Therefore, the following tests and statistical methods were selected to examine the selected relations:

- Multidimensional cluster analysis to identify homogeneous subsets of objects (i.e., subgroups of factors) that are more "similar" to the objects from a given cluster as compared to the objects from other clusters. In the above-mentioned analysis, as the distance function we used the Euclidean distance [96].

- As the principle for connecting cluster, the single linkage method was used, also called the nearest neighbour method. In this method, the distance between two clusters is determined by the distance between the two nearest objects (nearest neighbours) belonging to different clusters [96]. The grouping of objects (factors) was performed with the hierarchical agglomeration method, which allows us to generate hierarchically ordered clusters, which can be presented in the form of a hierarchical tree (dendrogram), presenting the distances between the objects.

- Mann-Whitney's U-test was used to compare two groups in terms of variables of a ratio or sequential nature [97]. As a measure of the size of the result, Glass's rank two-series correlation coefficient was used [98]. It is values from the $<-1,1>$ range (the higher the absolute value, the greater the result). 
Spearman rank-order correlation examines the interdependence between two variables of a ratio and/or sequential nature [97]. In the course of statistical verification of the collected material, the level of significance of the results obtained was assumed to be $p<0.05$. The value of the analysed non-measurable parameters was presented by means of percentage distribution, while of those measurable by means of descriptive statistics. Statistica v.13.3 PL statistical package by StatSoft, Inc., USA was used for the calculations.

The survey, which lasted from the beginning of January to the end of June 2019, involved a total of 593 people, 193 of whom were excluded from the survey due to the lack of innovation introduced in their companies over the past three years. In other words, the first question in the survey was of a qualifying nature. If, in the opinion of the respondent, no innovations had been introduced in their company in the last three years, they were not qualified for answering further questions in the survey. Thus, the final number of respondents was 400, from 310 companies, including 72 women and 328 men. The research questionnaire was sent out via e-mail, in the form of separate links to complete the survey for each company. When estimating the minimum sample size, the formula [99] for sample size for qualitative characteristics (with a finite sample) was applied.

PKD62 code meaning "Computer programming and consultancy activities and related services" in Poland was very often indicated together with many PKD codes not associated with the IT industry, defining the subject of activity of companies employing up to 9 people. Therefore, it was decided that for the purposes of this research only companies reporting PKD62 code and declaring employment of 10 or more people would be considered. Therefore, it was assumed that there would be a general population of 200,254 [100] employees working at 1370 [101] IT companies, 50\% of whom have implemented innovations. Moreover, a 95\% probability was assumed that the result obtained in the studies would not differ from the actual value in the population by more than $5 \%$. Thus, the minimum sample size was estimated at 300 companies and 383 IT employees. The vast majority of the respondents were people with higher education degrees, with little professional experience at the current company, working at various positions. Therefore, it can be concluded that in the IT industry in Poland the majority of employees are men with higher education degrees, aged about 30, who often change their employer. Table 1 below provides detailed information on the respondents.

Table 1. Basic information on the respondents.

\begin{tabular}{|c|c|c|c|}
\hline & & $n$ & $\%$ \\
\hline \multirow{4}{*}{ Education } & Primary & 6 & $1.50 \%$ \\
\hline & Vocational & 3 & $0.75 \%$ \\
\hline & Secondary & 93 & $23.25 \%$ \\
\hline & Higher & 298 & $74.50 \%$ \\
\hline \multirow{4}{*}{ Seniority with current employer } & $0-2$ years & 203 & $50.75 \%$ \\
\hline & $3-6$ years & 109 & $27.25 \%$ \\
\hline & $7-10$ years & 40 & $10.00 \%$ \\
\hline & Over 10 years & 48 & $12.00 \%$ \\
\hline \multirow{7}{*}{ Position } & Administrative employee & 25 & $6.25 \%$ \\
\hline & Specialist & 91 & $22.75 \%$ \\
\hline & Programmer & 128 & $32.00 \%$ \\
\hline & Lower-level manager & 32 & $8.00 \%$ \\
\hline & Higher-level manager & 31 & $7.75 \%$ \\
\hline & Management Board & 22 & $5.50 \%$ \\
\hline & Other & 71 & $17.75 \%$ \\
\hline
\end{tabular}

Source: Authors' own work. 
The majority of IT companies in Poland have been present on the market for a long time and are financed mainly with Polish and mixed (Polish and foreign) capital, which is a good prognosis for the development of Polish economy. Detailed information on the respondents' companies is presented in Table 2.

Table 2. Basic information on the respondents' companies.

\begin{tabular}{|c|c|c|c|}
\hline & & $n$ & $\%$ \\
\hline \multirow{4}{*}{ Ownership structure } & Exclusively Polish capital & 145 & $36.25 \%$ \\
\hline & Polish and foreign capital & 149 & $37.25 \%$ \\
\hline & Exclusively foreign capital & 40 & $10.00 \%$ \\
\hline & No opinion & 66 & $16.50 \%$ \\
\hline \multirow{4}{*}{ Employment figure } & 10-49 employees & 99 & $24.75 \%$ \\
\hline & 50-100 employees & 94 & $23.50 \%$ \\
\hline & 101-249 employees & 77 & $19.25 \%$ \\
\hline & 250 and more employees & 130 & $32.50 \%$ \\
\hline \multirow{4}{*}{ Period of existence } & Up to 3 years & 42 & $10.50 \%$ \\
\hline & $4-6$ years & 66 & $16.50 \%$ \\
\hline & $7-10$ years & 83 & $20.75 \%$ \\
\hline & 11 and more years & 209 & $52.25 \%$ \\
\hline
\end{tabular}

\section{Results and Discussion}

In the first part of the result analysis, the distribution of answers to the individual questionnaire questions was evaluated. The respondents were asked about various issues related to their attitudes towards innovation, but the main part of the questionnaire concerned an assessment of particular factors related to organisational culture in terms of their impact on the adoption of innovation in the company. The key issue here was to divide the innovation process into stages, i.e., the innovation initiation stage, the decision on adopting innovation stage and the innovation implementation stage. The first step in this part of the analysis was to assess the attitudes of the respondents to innovation in the company. The respondents showed a rather positive attitude towards introducing innovations in the company. Most of the respondents associated innovation with the possibility of development $(70.25 \%)$ and learning new programs $(52.50 \%)$. One in two people treated innovation in the company as an opportunity for personal development $(49.00 \%)$ and a chance to prove themselves $(50.50 \%)$. A significant percentage of the respondents $(43.25 \%)$ associated innovation with a challenge that they would be willing to take up. In addition, the respondents were mostly (46.75\%) happy about introducing future innovations in the company, which additionally confirms their positive attitude to this issue. The surveyed employees of IT companies in Poland showed their commitment to introducing innovation in their companies. One in two respondents (50.25\%) tended to identify with the company's objectives and planned or currently implemented innovations $(17.50 \%$, of the respondents answered "definitely", which gives a total of $67.75 \%$ of people who identify with the above-mentioned issues in the company). In addition, the majority of the respondents were ready to undertake planning or innovation activities ("definitely" and "probably" answers were given by $76.25 \%$ of the respondents in total).

The next step of the analysis was to compare the individual stages of the process of introducing innovation in terms of the perception by the surveyed employees of IT companies in Poland of the influence of factors related to organisational culture in the context of adopting innovation. Analysis with Mann-Whitney's rank U-test showed statistically significant differences between the different stages in terms of perceiving the impact of 10 out of 15 organisational culture-related factors on the adoption 
of innovation. The impact of the above ten factors on organisational culture was less frequently seen at the stage of innovation initiation compared to the later stages of innovation introduction. This concerns factors such as: Creation by the company of favourable conditions for development of employees' competences $\left(Z=5.39 ; p<0.001 ; r_{g}=0.42\right)$; ensuring employees' independence $(Z=-5.11 ; p<0.001$; $\left.r_{g}=-0.33\right)$; sense of co-ownership and control over one's own work $\left(Z=-6.79 ; p<0.001 ; r_{g}=-0.44\right)$; encouraging employees to continue learning $\left(Z=4.68 ; p<0.001 ; r_{g}=0.30\right)$; exchanging knowledge between different company departments $\left(Z=-7.34 ; p<0.001 ; r_{g}=-0.50\right)$; shared commitments with regard to implementing a specific project $\left(Z=-7.31 ; p<0.001 ; r_{g}=-0.38\right)$; promotion by managers of the value of dialogue, cooperation and partnership $\left(Z=-5.09 ; p<0.001 ; r_{g}=-0.26\right)$; encouraging staff to discuss each other's ideas $\left(Z=-3.55 ; p<0.001 ; r_{g}=-0.23\right)$; regular brainstorming $(Z=-5.46$; $\left.p<0.001 ; \mathrm{r}_{\mathrm{g}}=-0.44\right)$ and mutual trust within the team or organisation $\left(Z=6.87 ; p<0.001 ; \mathrm{r}_{\mathrm{g}}=0.38\right)$. These factors were less frequently assigned any role at the innovation initiation stage in the process of innovation adoption. In other words, according to the respondents, adoption of innovation in the company was more dependent on the application of the above-mentioned factors at the stage of making a decision on adoption of innovation and at the stage of its implementation. Most of the respondents noticed the impact of every factor related to organisational culture on the adoption of innovation at every stage of innovation introduction. Detailed results are presented in Table 3.

Then, assessments of the form of the impact of factors related to company organisational culture in terms of adopting innovation at the different stages of the process were compared. Spearman rank-order correlation analysis showed a statistically significant relationship between the assessment of the form of the impact of 7 out of 15 factors related to organisational culture and the degree of advancement of innovation, understood as individual stages of this process. It turned out that with the level of advancement of the above-mentioned process (i.e., with each successive stage of introducing innovation), a significantly smaller role in the adoption of innovation was attributed to such factors as: Giving employees an opportunity to challenge existing solutions $(\mathrm{R}=-0.2 ; \mathrm{t}(\mathrm{N}-2)=-7.11 ; p<0.001)$; freedom to experiment and take risks at work $(\mathrm{R}=-0.15 ; \mathrm{t}(\mathrm{N}-2)=-5.24 ; p<0.001)$ and regular brainstorming $(\mathrm{R}=-0.15 ; \mathrm{t}(\mathrm{N}-2)=-5.24 ; p<0.001)$. The opposite was true for factors such as: Sense of co-ownership and control over one's own work $(\mathrm{R}=0.07 ; \mathrm{t}(\mathrm{N}-2)=2.2 ; p<0.05)$; exchanging knowledge between different company departments $(\mathrm{R}=0.07 ; \mathrm{t}(\mathrm{N}-2)=2.3 ; p<0.05)$; shared commitments with regard to implementing a specific project $(\mathrm{R}=0.1 ; \mathrm{t}(\mathrm{N}-2)=3.38 ; p<0.001)$ and mutual trust within the team or organisation $(\mathrm{R}=0.09 ; \mathrm{t}(\mathrm{N}-2)=3.06 ; p<0.01)$, where with each successive stage of innovation introduction, a significantly increasing role was assigned to them in adoption of innovation. In the case of other factors related to organisational culture, no statistically significant relationship was found with the level of advancement of the innovation introduction process (i.e., differences between the various stages). Table 4 provides details on this.

Taking into account the average assessments of the form of impact on the adoption of innovation attributed to the individual organisational culture factors, the next step of the analysis verified the differences in this respect between the various stages of innovation introduction. To this end, Spearman rank-order correlation analysis was applied, examining the relationship between average assessments of the individual organisational culture factors and the degree of advancement of the innovation introduction process. A statistically significant relationship was found between the average assessment of the impact of organisational culture and the degree of advancement of the innovation introduction process $(\mathrm{R}=-0.08 ; \mathrm{t}(\mathrm{N}-2)=-2.82 ; p<0.01)$, with this relationship being negative, i.e., the respondents attributed a greater role to factors from this group in adopting innovation at the first stage $(\mathrm{M}=4.08$; $\mathrm{SD}=0.6)$ than in the later ones: Deciding on adopting innovation $(\mathrm{M}=3.97$; $\mathrm{SD}=0.53)$ and implementing innovation $(\mathrm{M}=3.97 ; \mathrm{SD}=0.51)$. 
Table 3. Comparison of the stages of the innovation introduction process in terms of the respondents' perception of the impact of individual factors related to organisational culture on innovation adoption.

\begin{tabular}{|c|c|c|c|c|c|c|c|c|c|}
\hline & & \multicolumn{2}{|c|}{ Innovation Initiation Stage } & \multicolumn{2}{|c|}{$\begin{array}{l}\text { Decision on Adopting } \\
\text { Innovation Stage }\end{array}$} & \multicolumn{2}{|c|}{$\begin{array}{c}\text { Innovation } \\
\text { Implementation Stage }\end{array}$} & \multirow{2}{*}{$\begin{array}{l}\text { Mann-Whitney's } \\
\text { U-Test }\end{array}$} & \multirow[t]{2}{*}{ Glass's rg } \\
\hline & & $\mathbf{N}$ & $\%$ & $\mathbf{N}$ & $\%$ & $\mathbf{N}$ & $\%$ & & \\
\hline \multirow{2}{*}{$\begin{array}{l}\text { Giving employees an opportunity to challenge existing } \\
\text { solutions }\end{array}$} & Yes & 392 & $98.00 \%$ & 390 & $97.50 \%$ & 390 & $97.50 \%$ & \multirow{2}{*}{$\begin{aligned} Z & =-0.44 \\
p & =0.659\end{aligned}$} & \multirow{2}{*}{-0.05} \\
\hline & No & 8 & $2.00 \%$ & 10 & $2.50 \%$ & 10 & $2.50 \%$ & & \\
\hline Ergonomics of workstations & No & 107 & $26.75 \%$ & 110 & $27.50 \%$ & 101 & $25.25 \%$ & $\begin{aligned} Z & =-0.45 \\
p & =0.651\end{aligned}$ & -0.02 \\
\hline \multirow{2}{*}{$\begin{array}{l}\text { Creation by the company of favourable conditions for } \\
\text { development of employees' competences }\end{array}$} & Yes & 357 & $89.25 \%$ & 392 & $98.00 \%$ & 392 & $98.00 \%$ & \multirow{2}{*}{$\begin{array}{l}Z=5.39 \\
p<0.001\end{array}$} & \multirow{2}{*}{0.42} \\
\hline & No & 43 & $10.75 \%$ & 8 & $2.00 \%$ & 8 & $2.00 \%$ & & \\
\hline \multirow{2}{*}{ Sense of co-ownership and control over one's own work } & Yes & 340 & $85.00 \%$ & 384 & $96.00 \%$ & 392 & $98.00 \%$ & \multirow{2}{*}{$\begin{array}{l}\mathrm{Z}=-6.79 \\
\mathrm{p}<0.001\end{array}$} & \multirow{2}{*}{-0.44} \\
\hline & No & 60 & $15.00 \%$ & 16 & $4.00 \%$ & 8 & $2.00 \%$ & & \\
\hline \multirow{2}{*}{ Encouraging employees to continue learning } & Yes & 348 & $87.00 \%$ & 383 & $95.75 \%$ & 384 & $96.00 \%$ & \multirow{2}{*}{$\begin{array}{l}Z=4.68 \\
p<0.001\end{array}$} & \multirow{2}{*}{0.30} \\
\hline & No & 52 & $13.00 \%$ & 17 & $4.25 \%$ & 16 & $4.00 \%$ & & \\
\hline \multirow{2}{*}{ Freedom to experiment and take risks at work } & Yes & 391 & $97.75 \%$ & 380 & $95.00 \%$ & 383 & $95.75 \%$ & \multirow{2}{*}{$\begin{aligned} Z & =-1.39 \\
p & =0.165\end{aligned}$} & \multirow{2}{*}{-0.12} \\
\hline & No & 9 & $2.25 \%$ & 20 & $5.00 \%$ & 17 & $4.25 \%$ & & \\
\hline specific project & No & 86 & $21.50 \%$ & 36 & $9.00 \%$ & 16 & $4.00 \%$ & $p<0.001$ & -0.00 \\
\hline Promotion by managers of the value of dialogue, & Yes & 322 & $80.50 \%$ & 367 & $91.75 \%$ & 371 & $92.75 \%$ & $Z=-5.09$ & \\
\hline cooperation and partnership & No & 78 & $19.50 \%$ & 33 & $8.25 \%$ & 29 & $7.25 \%$ & $p<0.001$ & -0.26 \\
\hline Fncoura & Yes & 353 & $88.25 \%$ & 384 & $96.00 \%$ & 380 & $95.00 \%$ & $Z=-3.55$ & $0 ? 2$ \\
\hline Encouraging stanto discuss eacn onter s ineas & No & 47 & $11.75 \%$ & 16 & $4.00 \%$ & 20 & $5.00 \%$ & $p<0.001$ & -0.23 \\
\hline Reoular brainstorming & Yes & 394 & $98.50 \%$ & 392 & $98.00 \%$ & 360 & $90.00 \%$ & $Z=-5.46$ & R:14 \\
\hline Neguiat viantstorintuly & No & 6 & $1.50 \%$ & 8 & $2.00 \%$ & 40 & $10.00 \%$ & $p<0.001$ & -0.44 \\
\hline Openness to new solutions and flexibility in & Yes & 389 & $97.25 \%$ & 395 & $98.75 \%$ & 393 & $98.25 \%$ & $\mathrm{Z}=0.97$ & 012 \\
\hline solving problems & No & 11 & $2.75 \%$ & 5 & $1.25 \%$ & 7 & $1.75 \%$ & $p=0.331$ & 0.12 \\
\hline Mutual trust within the team / organisation & Yes & 319 & $79.75 \%$ & 374 & $93.50 \%$ & 382 & $95.50 \%$ & $\mathrm{Z}=6.87$ & 038 \\
\hline 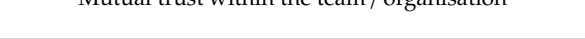 & No & 81 & $20.25 \%$ & 26 & $6.50 \%$ & 18 & $4.50 \%$ & $p<0.001$ & 0.38 \\
\hline Proper recoonition and incentives for employees & Yes & 390 & $97.50 \%$ & 386 & $96.50 \%$ & 389 & $97.25 \%$ & $Z=-0.2 ;$ & $=0$ \\
\hline
\end{tabular}


Table 4. Comparison of stages of the innovation introduction process in terms of the respondents' assessment of the form of impact of individual factors related to organisational culture on the adoption of innovation.

\begin{tabular}{|c|c|c|c|c|c|c|c|c|}
\hline & & \multicolumn{6}{|c|}{ Descriptive Statistics } & \multirow{3}{*}{$\begin{array}{l}\text { Spearman Rank-Order } \\
\text { Correlation }\end{array}$} \\
\hline & & \multirow{2}{*}{$\begin{array}{l}\text { Average } \pm \text { Standard } \\
\text { Deviation }\end{array}$} & \multirow{2}{*}{$\begin{array}{l}\text { Median; } \\
\text { (Q25-Q75) }\end{array}$} & \multirow{2}{*}{ Min-Max } & \multicolumn{2}{|c|}{ Confidence Range } & \multirow{2}{*}{ Standard Error } & \\
\hline & & & & & $-95 \%$ & $+95 \%$ & & \\
\hline \multirow{3}{*}{$\begin{array}{l}\text { Giving employees an opportunity } \\
\text { to challenge existing solutions }\end{array}$} & Innovation initiation stage & $3.9 \pm 1.18$ & $4(3-5)$ & $1-5$ & 3.78 & 4.01 & 0.06 & \multirow{3}{*}{$\begin{aligned} \mathrm{R} & =-0.2 ; \\
\mathrm{t}(\mathrm{N}-2) & =-7.11 \\
p & <0.001\end{aligned}$} \\
\hline & Decision on adopting innovation stage & $3.67 \pm 1.07$ & $4(3-4)$ & $1-5$ & 3.57 & 3.78 & 0.05 & \\
\hline & Innovation implementation stage & $3.37 \pm 1.15$ & $4(2-4)$ & $1-5$ & 3.25 & 3.48 & 0.06 & \\
\hline \multirow{3}{*}{ Ergonomics of workstations } & Innovation initiation stage & $3.94 \pm 0.86$ & $4(3-5)$ & $2-5$ & 3.84 & 4.04 & 0.05 & \multirow{3}{*}{$\begin{array}{c}\mathrm{R}=0.02 ; \\
\mathrm{t}(\mathrm{N}-2)=0.54 \\
\quad p=0.592\end{array}$} \\
\hline & Decision on adopting innovation stage & $3.85 \pm 0.89$ & $4(3-5)$ & $2-5$ & 3.75 & 3.95 & 0.05 & \\
\hline & Innovation implementation stage & $3.98 \pm 0.86$ & $4(3-5)$ & $2-5$ & 3.88 & 4.08 & 0.05 & \\
\hline \multirow{3}{*}{$\begin{array}{l}\text { Creation by the company of } \\
\text { favourable conditions for } \\
\text { development of employees' } \\
\text { competences }\end{array}$} & Innovation initiation stage & $4.26 \pm 0.84$ & $4(4-5)$ & $1-5$ & 4.17 & 4.34 & 0.04 & \multirow{3}{*}{$\begin{array}{c}\mathrm{R}=0.01 \\
\mathrm{t}(\mathrm{N}-2)=0.2 \\
p=0.845\end{array}$} \\
\hline & Decision on adopting innovation stage & $4.21 \pm 0.84$ & $4(4-5)$ & $1-5$ & 4.13 & 4.29 & 0.04 & \\
\hline & Innovation implementation stage & $4.27 \pm 0.83$ & $4(4-5)$ & $1-5$ & 4.19 & 4.35 & 0.04 & \\
\hline \multirow{3}{*}{$\begin{array}{l}\text { Ensuring employees' } \\
\text { independence }\end{array}$} & Innovation initiation stage & $3.55 \pm 1.07$ & $4(3-4)$ & $1-5$ & 3.44 & 3.67 & 0.06 & \multirow{3}{*}{$\begin{array}{l}\mathrm{R}=0.01 ; \\
\mathrm{t}(\mathrm{N}-2)=0.48 ; \\
\quad p=0.629\end{array}$} \\
\hline & Decision on adopting innovation stage & $3.58 \pm 1$ & $4(3-4)$ & $1-5$ & 3.48 & 3.68 & 0.05 & \\
\hline & Innovation implementation stage & $3.58 \pm 1.06$ & $4(3-4)$ & $1-5$ & 3.48 & 3.69 & 0.05 & \\
\hline \multirow{3}{*}{$\begin{array}{l}\text { Sense of co-ownership and control } \\
\text { over one's own work }\end{array}$} & Innovation initiation stage & $3.8 \pm 0.91$ & $4(3-4)$ & $1-5$ & 3.70 & 3.90 & 0.05 & \multirow{3}{*}{$\begin{array}{c}\mathrm{R}=0.07 \\
\mathrm{t}(\mathrm{N}-2)=2.2 \\
p<0.05\end{array}$} \\
\hline & Decision on adopting innovation stage & $3.86 \pm 0.86$ & $4(3-4)$ & $1-5$ & 3.77 & 3.95 & 0.04 & \\
\hline & Innovation implementation stage & $3.94 \pm 0.92$ & $4(3-5)$ & $1-5$ & 3.85 & 4.03 & 0.05 & \\
\hline \multirow{3}{*}{$\begin{array}{l}\text { Encouraging employees to } \\
\text { continue learning }\end{array}$} & Innovation initiation stage & $3.92 \pm 0.96$ & $4(3-5)$ & $1-5$ & 3.82 & 4.02 & 0.05 & \multirow{3}{*}{$\begin{array}{c}\mathrm{R}=0.04 \\
\mathrm{t}(\mathrm{N}-2)=1.22 \\
\quad p=0.223\end{array}$} \\
\hline & Decision on adopting innovation stage & $3.98 \pm 0.88$ & $4(4-5)$ & $1-5$ & 3.89 & 4.07 & 0.05 & \\
\hline & Innovation implementation stage & $4.01 \pm 0.91$ & $4(4-5)$ & $1-5$ & 3.91 & 4.10 & 0.05 & \\
\hline \multirow{3}{*}{$\begin{array}{l}\text { Freedom to experiment and take } \\
\text { risks at work }\end{array}$} & Innovation initiation stage & $4 \pm 1.05$ & $4(3-5)$ & $1-5$ & 3.90 & 4.11 & 0.05 & \multirow{3}{*}{$\begin{aligned} \mathrm{R} & =-0.15 \\
\mathrm{t}(\mathrm{N}-2) & =-5.24 \\
p & <0.001\end{aligned}$} \\
\hline & Decision on adopting innovation stage & $3.78 \pm 1.01$ & $4(3-5)$ & $1-5$ & 3.68 & 3.88 & 0.05 & \\
\hline & Innovation implementation stage & $3.62 \pm 1.09$ & $4(3-5)$ & $1-5$ & 3.51 & 3.73 & 0.06 & \\
\hline \multirow{3}{*}{$\begin{array}{l}\text { Exchanging knowledge between } \\
\text { different company departments }\end{array}$} & Innovation initiation stage & $4.07 \pm 0.82$ & $4(4-5)$ & $1-5$ & 3.98 & 4.16 & 0.04 & \multirow{3}{*}{$\begin{array}{c}\mathrm{R}=0.07 \\
\mathrm{t}(\mathrm{N}-2)=2.3 \\
p<0.05\end{array}$} \\
\hline & Decision on adopting innovation stage & $4.12 \pm 0.82$ & $4(4-5)$ & $1-5$ & 4.04 & 4.20 & 0.04 & \\
\hline & Innovation implementation stage & $4.19 \pm 0.86$ & $4(4-5)$ & $1-5$ & 4.10 & 4.27 & 0.04 & \\
\hline \multirow{3}{*}{$\begin{array}{l}\text { Shared commitments with regard } \\
\text { to implementing a specific project }\end{array}$} & Innovation initiation stage & $3.76 \pm 0.92$ & $4(3-4)$ & $1-5$ & 3.66 & 3.87 & 0.05 & \multirow{3}{*}{$\begin{array}{c}\mathrm{R}=0.1 \\
\mathrm{t}(\mathrm{N}-2)=3.38 \\
p<0.001\end{array}$} \\
\hline & Decision on adopting innovation stage & $3.77 \pm 0.85$ & $4(3-4)$ & $1-5$ & 3.68 & 3.86 & 0.04 & \\
\hline & Innovation implementation stage & $3.97 \pm 0.96$ & $4(3-5)$ & $1-5$ & 3.87 & 4.07 & 0.05 & \\
\hline \multirow{3}{*}{$\begin{array}{l}\text { Promotion by managers of the } \\
\text { value of dialogue, } \\
\text { cooperation and partnership }\end{array}$} & Innovation initiation stage & $3.93 \pm 0.91$ & $4(3-5)$ & $1-5$ & 3.84 & 4.03 & 0.05 & \multirow{3}{*}{$\begin{array}{c}\mathrm{R}=0.02 ; \\
\mathrm{t}(\mathrm{N}-2)=0.54 ; \\
p=0.586\end{array}$} \\
\hline & Decision on adopting innovation stage & $3.86 \pm 0.88$ & $4(3-5)$ & $1-5$ & 3.77 & 3.95 & 0.05 & \\
\hline & Innovation implementation stage & $3.96 \pm 0.9$ & $4(3-5)$ & $1-5$ & 3.87 & 4.05 & 0.05 & \\
\hline
\end{tabular}


Table 4. Cont

\begin{tabular}{|c|c|c|c|c|c|c|c|c|}
\hline & & \multicolumn{6}{|c|}{ Descriptive Statistics } & \multirow{3}{*}{$\begin{array}{l}\text { Spearman Rank-Order } \\
\text { Correlation }\end{array}$} \\
\hline & & \multirow{2}{*}{$\begin{array}{l}\text { Average } \pm \text { Standard } \\
\text { Deviation }\end{array}$} & \multirow{2}{*}{$\begin{array}{l}\text { Median; } \\
\text { (Q25-Q75) }\end{array}$} & \multirow{2}{*}{ Min-Max } & \multicolumn{2}{|c|}{ Confidence Range } & \multirow{2}{*}{ Standard Error } & \\
\hline & & & & & $-95 \%$ & $+95 \%$ & & \\
\hline \multirow{3}{*}{$\begin{array}{l}\text { Encouraging staff to discuss each } \\
\text { other's ideas }\end{array}$} & Innovation initiation stage & $3.95 \pm 0.95$ & $4(3-5)$ & $1-5$ & 3.86 & 4.05 & 0.05 & \multirow{3}{*}{$\begin{array}{c}\mathrm{R}=-0.02 ; \\
\mathrm{t}(\mathrm{N}-2)=-0.63 ; \\
p=0.53\end{array}$} \\
\hline & Decision on adopting innovation stage & $3.94 \pm 0.96$ & $4(3-5)$ & $1-5$ & 3.84 & 4.03 & 0.05 & \\
\hline & Innovation implementation stage & $3.92 \pm 0.91$ & $4(3-5)$ & $1-5$ & 3.83 & 4.01 & 0.05 & \\
\hline \multirow{3}{*}{ Regular brainstorming } & Innovation initiation stage & $4.24 \pm 0.93$ & $5(4-5)$ & $1-5$ & 4.15 & 4.34 & 0.05 & \multirow{3}{*}{$\begin{array}{c}\mathrm{R}=-0.16 \\
\mathrm{t}(\mathrm{N}-2)=-5.58 \\
p<0.001\end{array}$} \\
\hline & Decision on adopting innovation stage & $4.1 \pm 0.92$ & $4(4-5)$ & $1-5$ & 4.01 & 4.19 & 0.05 & \\
\hline & Innovation implementation stage & $3.9 \pm 0.97$ & $4(3-5)$ & $1-5$ & 3.80 & 4.00 & 0.05 & \\
\hline \multirow{3}{*}{$\begin{array}{l}\text { Openness to new solutions and } \\
\text { flexibility in solving problems }\end{array}$} & Innovation initiation stage & $4.33 \pm 0.89$ & $5(4-5)$ & $1-5$ & 4.24 & 4.42 & 0.05 & \multirow{3}{*}{$\begin{array}{c}\mathrm{R}=-0.06 \\
\mathrm{t}(\mathrm{N}-2)=-1.92 \\
p<0.055\end{array}$} \\
\hline & Decision on adopting innovation stage & $4.26 \pm 0.87$ & $4(4-5)$ & $1-5$ & 4.17 & 4.34 & 0.04 & \\
\hline & Innovation implementation stage & $4.22 \pm 0.91$ & $4(4-5)$ & $1-5$ & 4.13 & 4.31 & 0.05 & \\
\hline \multirow{3}{*}{$\begin{array}{l}\text { Mutual trust within the team / } \\
\text { organisation }\end{array}$} & Innovation initiation stage & $4.15 \pm 0.86$ & $4(4-5)$ & $1-5$ & 4.06 & 4.25 & 0.05 & \multirow{3}{*}{$\begin{array}{c}\mathrm{R}=0.09 \\
\mathrm{t}(\mathrm{N}-2)=3.06 \\
p<0.01\end{array}$} \\
\hline & Decision on adopting innovation stage & $4.16 \pm 0.8$ & $4(4-5)$ & $1-5$ & 4.08 & 4.24 & 0.04 & \\
\hline & Innovation implementation stage & $4.33 \pm 0.81$ & $5(4-5)$ & $1-5$ & 4.25 & 4.41 & 0.04 & \\
\hline \multirow{3}{*}{$\begin{array}{l}\text { Proper recognition and incentives } \\
\text { for employees }\end{array}$} & Innovation initiation stage & $4.33 \pm 0.87$ & $5(4-5)$ & $1-5$ & 4.24 & 4.42 & 0.04 & \multirow{3}{*}{$\begin{array}{c}\mathrm{R}=0.01 \\
\mathrm{t}(\mathrm{N}-2)=0.33 \\
p=0.743\end{array}$} \\
\hline & Decision on adopting innovation stage & $4.32 \pm 0.87$ & $5(4-5)$ & $1-5$ & 4.23 & 4.41 & 0.04 & \\
\hline & Innovation implementation stage & $4.34 \pm 0.88$ & $5(4-5)$ & $1-5$ & 4.25 & 4.43 & 0.04 & \\
\hline
\end{tabular}

Source: Authors' own work. 
In order to identify factors similarly assessed at the individual stages, and thus able to provide guidelines for the proper implementation of innovation at companies, a multidimensional cluster analysis was used. In this analysis, the agglomeration method (this method assumes that initially each object (factor) is a separate cluster; then, it gradually combines the closest objects into new clusters, until one cluster is formed) was used to visually identify the number of groups of factors (clusters) similar to each other in terms of the assessment of the form of impact on adoption of innovation (distances between the clusters were calculated using the single linkage method). Cluster analysis performed with the agglomeration method showed that the assessments of the individual factors related to organisational culture at the stage of innovation initiation were similar and thus many of the above-mentioned factors were part of one cluster. Analysis of the following dendrogram (Figure 1) shows that there were four clusters, three of which were one-element and concerned factors such as: Giving workers an opportunity to challenge existing solutions; ensuring employees' independence; the freedom to experiment and take risks at work. The other factors formed one cluster, and this concerned factors such as: ergonomics of work stations; creation by the company of favourable conditions for the development of employees' competences; knowledge exchange between different company departments; mutual trust within the team/organisation; proper recognition and incentives for employees; promotion by managers of the values of dialogue, cooperation and partnership; openness to new solutions and flexibility in solving problems; shared commitments to the implementation of a specific project; encouraging employees to continue learning; encouraging employees to discuss each other's ideas; sense of co-ownership and control over one's own work; regular brainstorming.

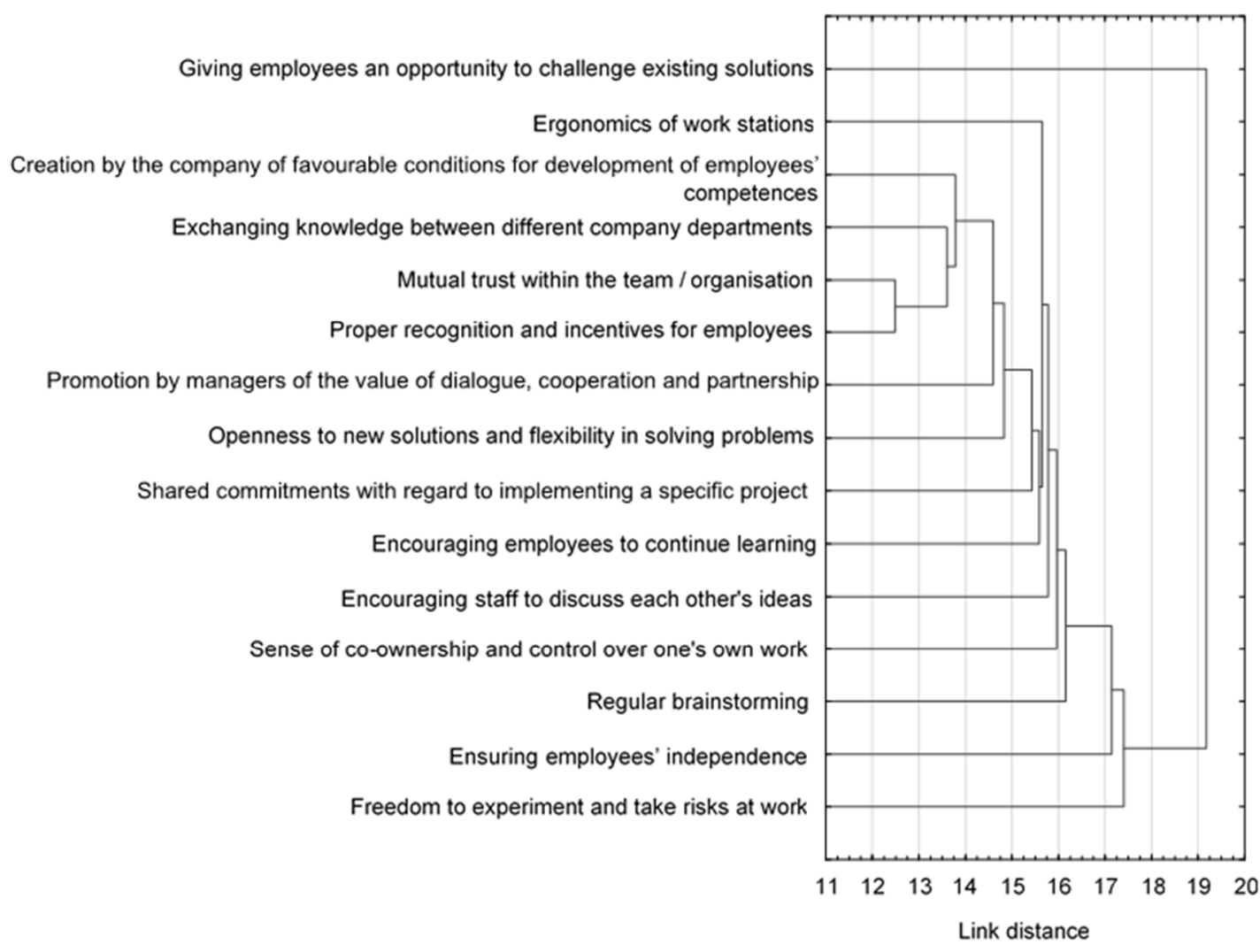

Figure 1. The dendrogram obtained for the analysed factors related to organisational culture in terms of their impact on adoption of innovation at the stage of innovation initiation (results of cluster analysis by agglomeration). Source: Authors' own work.

The cluster analysis with the use of the agglomeration method at the stage of the decision to adopt innovation indicated that many factors concerning organisational culture were similar, and thus 
many of the factors were part of one cluster. In the following dendrogram (Figure 2), seven clusters can be seen, six of which were single-piece ones and concerned factors such as: Giving employees an opportunity to challenge existing solutions; shared commitments to implementing a specific project; regular brainstorming; encouraging employees to discuss each other's ideas; freedom to experiment and take risks at work; ensuring employees' independence. All other factors in this category formed one cluster, and this concerned factors such as: Ergonomics of work stations; creation by the company of favourable conditions for development of employees' competences; mutual trust within the team/organisation; proper recognition and incentives for employees; openness to new solutions and flexibility in solving problems; knowledge exchange between different company departments; encouraging employees to continue learning; promotion by managers of the value of dialogue, cooperation and partnership; sense of co-ownership and control over one's own work. Importantly, within this cluster, two smaller groups of factors can be identified that are even more closely related in terms of assessment of the impact on adoption of innovation at the time of making the decision to adopt innovation. The first of the above-mentioned groups included: Creation by the company of favourable conditions for the development of employees' competences; mutual trust within the team or organisation; proper recognition and incentives for employees. The second group consisted of factors relating to encouraging workers to continue learning and managers promoting the values of dialogue, cooperation and partnership.

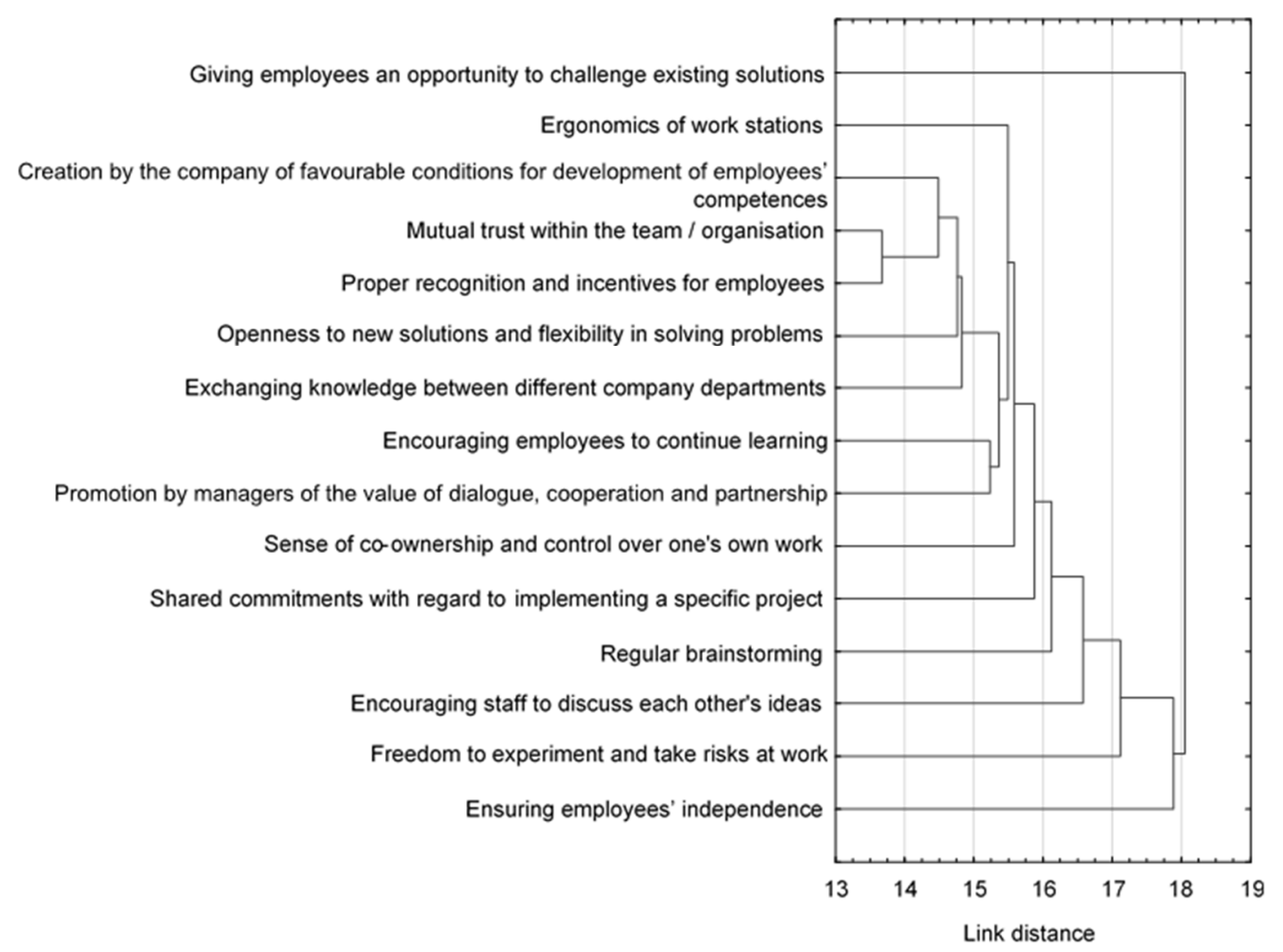

Figure 2. The dendrogram obtained for the analysed factors related to organisational culture in terms of their impact on adoption of innovation at the stage of making the decision to adopt innovation (results of cluster analysis by agglomeration). Source: Authors' own work.

Organisational culture factors were similarly assessed in terms of their impact on the adoption of innovation at the final stage of innovation implementation. Only giving employees an opportunity to question the existing solutions and freedom to experiment and take risks at work definitely differed from the other factors in the above-mentioned assessments, constituting two one-element clusters. Whereas in the case of the other factors, the distances between the subsequent factors, which, according 
to the principle of the agglomeration method, are less and less similar to the others, were not so clear. As a result, there is a large, 13-element cluster of factors. Within this cluster, a group of factors that are particularly close to each other in terms of the above-mentioned assessment can be observed. This concerns: Creation by the company of favourable conditions for the development of employees' competences; mutual trust; proper recognition and incentives for employees. Factors that differ slightly more from group in the assessment include exchange of knowledge between different company departments, promotion by managers of the values of dialogue, cooperation and partnership and encouraging employees to continue learning. The following dendrogram (Figure 3) illustrates the distances between the individual clusters and their constituent factors.

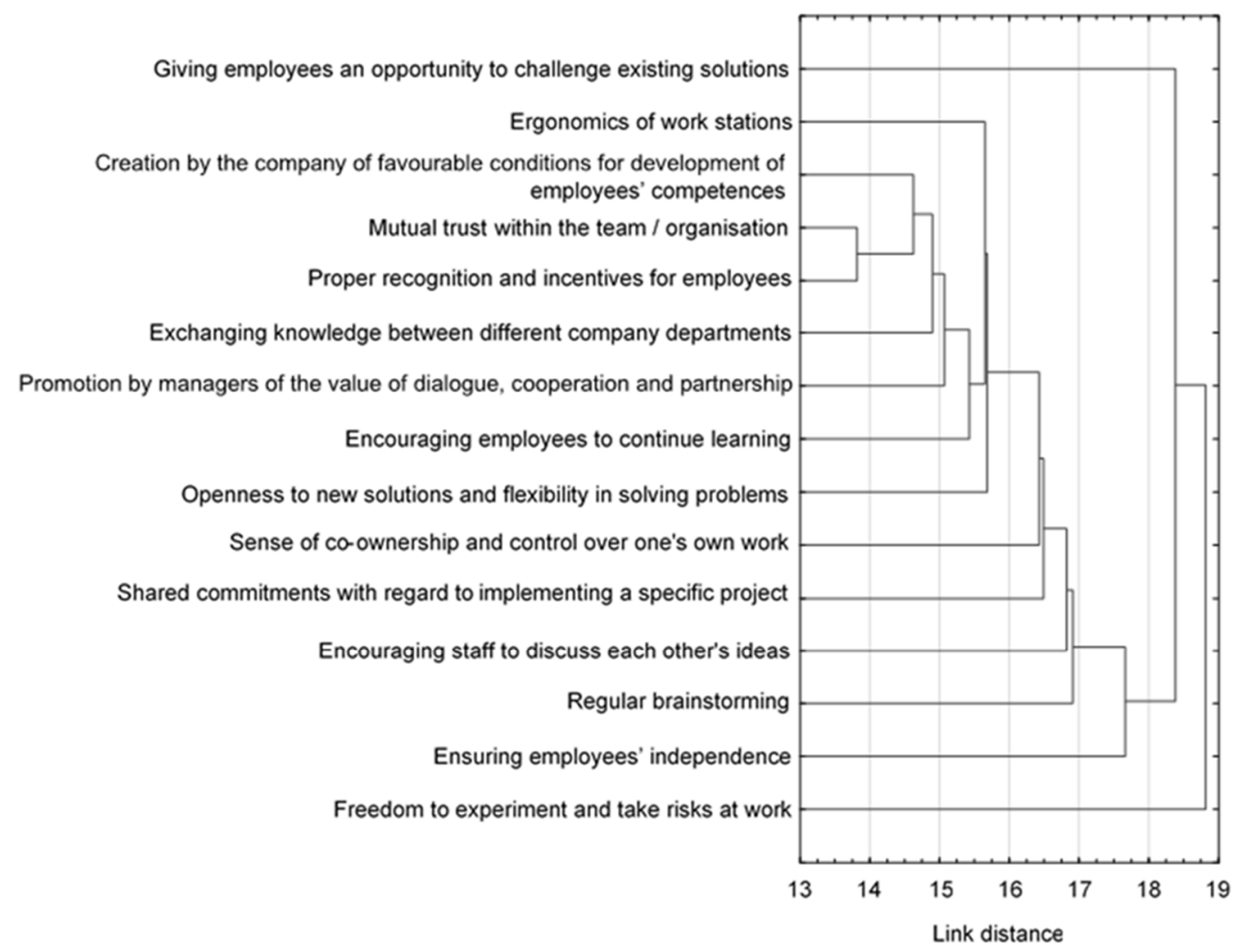

Figure 3. The dendrogram obtained for the analysed factors related to organisational culture in terms of their impact on adoption of innovation at the stage of innovation implementation (results of cluster analysis by agglomeration). Source: Authors' own work.

\section{Conclusions}

While summarising the above considerations, some scientific conclusions can be presented that may be interesting to both Polish and foreign scientists. On the basis of the research conducted it can be found that IT industry employees in Poland are rather positive about introducing innovations in the companies they work for. Most of them associate innovation with an opportunity to self-develop, learn new programs, improve their skills and prove themselves. Only few of them are afraid of innovation and see it as a threat. In addition, most respondents tended to identify with the company's objectives and planned or currently implemented innovations. Perhaps the specific nature of the IT industry, which has to introduce numerous innovations in order to survive, has contributed to some kind of familiarity with innovations and their positive perception among IT staff. This is a good sign of development for Poland, where the IT industry is a key driver of economic growth.

Another scientific conclusion identifies a research gap in the area of organisational culture factors that affect differently the various stages of innovation implementation in terms of innovation adoption. The analysis performed with Mann-Whitney's rank U-test showed statistically significant differences 
between the individual stages of introducing innovation in terms of the perceived impact of 10 out of 15 organisational culture factors on adoption of innovation, which confirmed the hypothesis of the article: Selected factors of organisational culture affect adoption of innovation differently at different stages of innovation introduction process. The confirmed hypothesis presented in the article opens a new research area and may be subject to further refinement. This includes factors such as: The company creating favourable conditions for the development of employees' competences; ensuring employees' independence; sense of co-ownership and control over one's own work; encouraging employees to continue learning; exchanging knowledge between different company departments; shared commitments to implementing a specific project; promotion by managers of the value of dialogue, cooperation and partnership; encouraging employees to discuss each other's ideas; regular brainstorming; mutual trust within the team or organisation. The impact of these factors on innovation adoption was less frequently seen at the stage of innovation initiation compared to the two later stages of innovation introduction. This means that selected factors related to organisational culture are more important not at the beginning of the innovation introduction process, when the first conclusions and plans concerning the innovation are created, but at the moment of making the decision to introduce the innovation and during its implementation.

The second part of the conclusions is of a practical nature and can be used by managers or other persons responsible for implementing innovation in their organisation. The factors presented below may serve as some kind of signposts for action to be taken at different stages of innovation implementation. For this purpose, it is worth determining the current stage of innovation implementation of the company and paying particular attention to assessment of individual factors, in particular those rated highest by the respondents at different stages of the innovation process. It is also worth remembering that a lack of individual organisational culture factors may prove to be a barrier to innovation implementation. All the examined factors were perceived by the respondents as having an impact on adoption of innovation; however, it is possible to indicate which of them have the greatest impact on the adoption of innovation at the individual stages of innovation introduction. At the stage of innovation initiation, the most important role in its adoption was assigned to the factor connected to proper recognition and incentives for employees. It is worth noting that the right motivation not only determines the results achieved at work, but also positively influences the acceptance of innovation. The second factor highly rated by the respondents was openness to new solutions and flexibility in solving problems. They should result from the company's organisational culture, but what is important is that they strengthen the relationship of trust and honesty within the company. Therefore, any doubts and problems should be analysed and solved together. The third highly rated factor was the creation by the company of favourable conditions for the development of employees' competences. Such an option allows to maintain the current qualifications of the employed staff and to ensure constantly updated knowledge. Properly selected training combined with management not only increases the efficiency of employee, but can also provide the company with financial benefits and openness to innovation. The fourth highly rated factor was regular brainstorming, which makes it possible to meet with the most diverse group of participants (in terms of age, gender, experience in a given field), who, supervised by the moderator, try to solve a given problem. This long-established method is particularly important at the first stage of innovation introduction because the reasoning of non-experts goes beyond certain patterns and can generate and foster innovation. At the stage of making the decision to adopt innovation, the greatest role in its adoption was attributed to factors analogous to those from the first stage, with the exception of regular brainstorming, which was not rated as high at the second stage. It can therefore be assumed that regular brainstorming is most important for adoption of innovation at the first stage of innovation introduction, i.e., when new concepts and ideas are born. At the stage of innovation implementation, the most important role in its adoption was attributed to the following factors: Proper recognition and incentives for employees (also highly rated at the other two stages); mutual trust within the team/organisation (highly rated only at this stage); creation by the company of favourable conditions for the development of employees' competences (also highly 
rated at the other two stages); openness to new solutions and flexibility in solving problems (also highly rated at the other two stages); knowledge exchange between different company departments (highly rated only at this stage). Thus, at the last stage of innovation, the impact of two factors was additionally noted, which were not so highly rated at the first two stages of innovation introduction. The first factor is mutual trust within the team/organisation, which is one of the most important elements of the organisation culture. If employees act in harmony and trust each other, they are able to pursue new challenges and accept innovation. Mutual trust encourages more open attitudes, greater resilience to risk and a desire for change. Moreover, trust in the organisation results in the employees' commitment and a desire to reach for completely new solutions. The second factor is exchange of knowledge between the different departments of the company, which is extremely important in the introduction of innovation, because this process certainly requires efficient communication. In this process, especially leaders should be aware of what is happening in the company's various departments, and information sharing allows for direct circulation of information, which in turn ensures adaptation to the rapidly changing situation in the organisation's environment.

The research presented in the article has some limitations. Firstly, it was carried out only in Poland, secondly, only in the IT industry and thirdly, only selected factors of organisational culture were taken into account. Further research on this issue is recommended in order to confirm the different impact of the factors on adoption of innovation at different stages of the innovation introduction process. On the basis of this concept it is possible to carry out detailed research on internal communication factors, which according to the literature also influence the acceptance of innovation, and to compare them with the presented results, taking into account different stages of innovation introduction.

Funding: This research received no external funding.

Conflicts of Interest: The author declares no conflict of interest.

\section{Appendix A}

Table A1. Distribution of factors and variables.

\begin{tabular}{|c|c|c|c|c|c|c|c|c|}
\hline & & \multicolumn{6}{|c|}{ Descriptive Statistics } & \multirow{3}{*}{$\begin{array}{c}\text { Alfa } \\
\text { Cronbacha }\end{array}$} \\
\hline & & \multirow{2}{*}{$\begin{array}{c}\text { Average } \pm \\
\text { Standard Deviation }\end{array}$} & \multirow{2}{*}{$\begin{array}{c}\text { Median; } \\
\text { (Q25-Q75) }\end{array}$} & \multirow{2}{*}{ Min-Max } & \multicolumn{2}{|c|}{ Confidence Range } & \multirow{2}{*}{$\begin{array}{l}\text { Standard } \\
\text { Error }\end{array}$} & \\
\hline & & & & & $-95 \%$ & $+95 \%$ & & \\
\hline \multirow{3}{*}{$\begin{array}{l}\text { Giving employees } \\
\text { an opportunity to } \\
\text { challenge existing } \\
\text { solutions }\end{array}$} & $\begin{array}{l}\text { Innovation initiation } \\
\text { stage }\end{array}$ & $3.82 \pm 1.29$ & $4(3-5)$ & $0-5$ & 3.69 & 3.95 & 0.06 & \multirow{3}{*}{0.75} \\
\hline & $\begin{array}{c}\text { Decision on } \\
\text { adopting innovation } \\
\text { stage }\end{array}$ & $3.58 \pm 1.2$ & $4(3-4)$ & $0-5$ & 3.46 & 3.70 & 0.06 & \\
\hline & $\begin{array}{c}\text { Innovation } \\
\text { implementation } \\
\text { stage }\end{array}$ & $3.29 \pm 1.25$ & $3(2-4)$ & $0-5$ & 3.16 & 3.41 & 0.06 & \\
\hline \multirow{3}{*}{$\begin{array}{l}\text { Ergonomics of } \\
\text { workstations }\end{array}$} & $\begin{array}{l}\text { Innovation initiation } \\
\text { stage }\end{array}$ & $2.89 \pm 1.89$ & $3(0-4)$ & $0-5$ & 2.70 & 3.07 & 0.09 & \multirow{3}{*}{0.97} \\
\hline & $\begin{array}{c}\text { Decision on } \\
\text { adopting innovation } \\
\text { stage }\end{array}$ & $2.79 \pm 1.88$ & $3(0-4)$ & $0-5$ & 2.61 & 2.98 & 0.09 & \\
\hline & $\begin{array}{c}\text { Innovation } \\
\text { implementation } \\
\text { stage }\end{array}$ & $2.97 \pm 1.88$ & $3.5(0-4.5)$ & $0-5$ & 2.79 & 3.16 & 0.09 & \\
\hline \multirow{3}{*}{$\begin{array}{l}\text { Creation by the } \\
\text { company of } \\
\text { favourable } \\
\text { conditions for } \\
\text { development of } \\
\text { employees' } \\
\text { competences }\end{array}$} & $\begin{array}{l}\text { Innovation initiation } \\
\text { stage }\end{array}$ & $3.8 \pm 1.54$ & $4(3-5)$ & $0-5$ & 3.65 & 3.95 & 0.08 & \multirow{3}{*}{0.73} \\
\hline & $\begin{array}{c}\text { Decision on } \\
\text { adopting innovation } \\
\text { stage }\end{array}$ & $4.13 \pm 1.02$ & $4(4-5)$ & $0-5$ & 4.02 & 4.23 & 0.05 & \\
\hline & $\begin{array}{c}\text { Innovation } \\
\text { implementation } \\
\text { stage }\end{array}$ & $4.18 \pm 1.02$ & $4(4-5)$ & $0-5$ & 4.08 & 4.28 & 0.05 & \\
\hline
\end{tabular}


Table A1. Cont.

\begin{tabular}{|c|c|c|c|c|c|c|c|c|}
\hline & & \multicolumn{6}{|c|}{ Descriptive Statistics } & \multirow{3}{*}{$\begin{array}{c}\text { Alfa } \\
\text { Cronbach }\end{array}$} \\
\hline & & \multirow{2}{*}{$\begin{array}{c}\text { Average } \pm \\
\text { Standard Deviation }\end{array}$} & \multirow{2}{*}{$\begin{array}{l}\text { Median; } \\
\text { (Q25-Q75) }\end{array}$} & \multirow{2}{*}{ Min-Max } & \multicolumn{2}{|c|}{ Confidence Range } & \multirow{2}{*}{$\begin{array}{l}\text { Standard } \\
\text { Error }\end{array}$} & \\
\hline & & & & & $-95 \%$ & $+95 \%$ & & \\
\hline \multirow{3}{*}{$\begin{array}{c}\text { Ensuring } \\
\text { employees' } \\
\text { independence }\end{array}$} & $\begin{array}{l}\text { Innovation initiation } \\
\text { stage }\end{array}$ & $3.06 \pm 1.59$ & $3(2-4)$ & $0-5$ & 2.90 & 3.21 & 0.08 & \multirow{3}{*}{0.76} \\
\hline & $\begin{array}{c}\text { Decision on } \\
\text { adopting innovation } \\
\text { stage }\end{array}$ & $3.44 \pm 1.2$ & $4(3-4)$ & $0-5$ & 3.32 & 3.56 & 0.06 & \\
\hline & $\begin{array}{c}\text { Innovation } \\
\text { implementation } \\
\text { stage } \\
\end{array}$ & $3.44 \pm 1.26$ & $4(3-4)$ & $0-5$ & 3.32 & 3.56 & 0.06 & \\
\hline \multirow{3}{*}{$\begin{array}{c}\text { Sense of } \\
\text { co-ownership and } \\
\text { control over one's } \\
\text { own work }\end{array}$} & $\begin{array}{c}\text { Innovation initiation } \\
\text { stage }\end{array}$ & $3.23 \pm 1.59$ & $4(3-4)$ & $0-5$ & 3.07 & 3.39 & 0.08 & \multirow{3}{*}{0.74} \\
\hline & $\begin{array}{c}\text { Decision on } \\
\text { adopting innovation } \\
\text { stage }\end{array}$ & $3.71 \pm 1.13$ & $4(3-4)$ & $0-5$ & 3.59 & 3.82 & 0.06 & \\
\hline & $\begin{array}{c}\text { Innovation } \\
\text { implementation } \\
\text { stage } \\
\end{array}$ & $3.86 \pm 1.06$ & $4(3-5)$ & $0-5$ & 3.75 & 3.96 & 0.05 & \\
\hline \multirow{3}{*}{$\begin{array}{l}\text { Encouraging } \\
\text { employees to } \\
\text { continue learning }\end{array}$} & $\begin{array}{c}\text { Innovation initiation } \\
\text { stage }\end{array}$ & $3.41 \pm 1.59$ & $4(3-5)$ & $0-5$ & 3.25 & 3.57 & 0.08 & \multirow{3}{*}{0.80} \\
\hline & $\begin{array}{c}\text { Decision on } \\
\text { adopting innovation } \\
\text { stage }\end{array}$ & $3.81 \pm 1.18$ & $4(3-5)$ & $0-5$ & 3.69 & 3.92 & 0.06 & \\
\hline & $\begin{array}{l}\text { Innovation } \\
\text { implementation } \\
\text { stage }\end{array}$ & $3.85 \pm 1.19$ & $4(3-5)$ & $0-5$ & 3.73 & 3.96 & 0.06 & \\
\hline \multirow{3}{*}{$\begin{array}{c}\text { Freedom to } \\
\text { experiment and } \\
\text { take risks at work }\end{array}$} & $\begin{array}{l}\text { Innovation initiation } \\
\text { stage }\end{array}$ & $3.91 \pm 1.2$ & $4(3-5)$ & $0-5$ & 3.79 & 4.03 & 0.06 & \multirow{3}{*}{0.80} \\
\hline & $\begin{array}{c}\text { Decision on } \\
\text { adopting innovation } \\
\text { stage }\end{array}$ & $3.59 \pm 1.28$ & $4(3-5)$ & $0-5$ & 3.46 & 3.72 & 0.06 & \\
\hline & $\begin{array}{l}\text { Innovation } \\
\text { implementation } \\
\text { stage }\end{array}$ & $3.47 \pm 1.3$ & $4(3-5)$ & $0-5$ & 3.34 & 3.59 & 0.06 & \\
\hline \multirow{3}{*}{$\begin{array}{c}\text { Exchanging } \\
\text { knowledge } \\
\text { between different } \\
\text { company } \\
\text { departments }\end{array}$} & $\begin{array}{l}\text { Innovation initiation } \\
\text { stage }\end{array}$ & $3.45 \pm 1.65$ & $4(3-5)$ & $0-5$ & 3.29 & 3.61 & 0.08 & \multirow{3}{*}{0.56} \\
\hline & $\begin{array}{c}\text { Decision on } \\
\text { adopting innovation } \\
\text { stage }\end{array}$ & $4.03 \pm 1.02$ & $4(4-5)$ & $0-5$ & 3.93 & 4.13 & 0.05 & \\
\hline & $\begin{array}{c}\text { Innovation } \\
\text { implementation } \\
\text { stage }\end{array}$ & $4.12 \pm 1.01$ & $4(4-5)$ & $0-5$ & 4.02 & 4.21 & 0.05 & \\
\hline \multirow{3}{*}{$\begin{array}{c}\text { Shared } \\
\text { commitments } \\
\text { with regard to } \\
\text { implementing a } \\
\text { specific project }\end{array}$} & $\begin{array}{c}\text { Innovation initiation } \\
\text { stage }\end{array}$ & $2.96 \pm 1.75$ & $3(2-4)$ & $0-5$ & 2.78 & 3.13 & 0.09 & \multirow{3}{*}{0.64} \\
\hline & $\begin{array}{c}\text { Decision on } \\
\text { adopting innovation } \\
\text { stage }\end{array}$ & $3.43 \pm 1.35$ & $4(3-4)$ & $0-5$ & 3.30 & 3.56 & 0.07 & \\
\hline & $\begin{array}{c}\text { Innovation } \\
\text { implementation } \\
\text { stage }\end{array}$ & $3.81 \pm 1.22$ & $4(3-5)$ & $0-5$ & 3.69 & 3.93 & 0.06 & \\
\hline \multirow{3}{*}{$\begin{array}{l}\text { Promotion by } \\
\text { managers of the } \\
\text { value of dialogue, } \\
\text { cooperation and } \\
\text { partnership }\end{array}$} & $\begin{array}{l}\text { Innovation initiation } \\
\text { stage }\end{array}$ & $3.17 \pm 1.76$ & $4(3-5)$ & $0-5$ & 2.99 & 3.34 & 0.09 & \multirow{3}{*}{0.83} \\
\hline & $\begin{array}{c}\text { Decision on } \\
\text { adopting innovation } \\
\text { stage }\end{array}$ & $3.55 \pm 1.36$ & $4(3-4)$ & $0-5$ & 3.41 & 3.68 & 0.07 & \\
\hline & $\begin{array}{c}\text { Innovation } \\
\text { implementation } \\
\text { stage }\end{array}$ & $3.67 \pm 1.35$ & $4(3-5)$ & $0-5$ & 3.54 & 3.80 & 0.07 & \\
\hline \multirow{3}{*}{$\begin{array}{l}\text { Encouraging staff } \\
\text { to discuss each } \\
\text { other's ideas }\end{array}$} & $\begin{array}{c}\text { Innovation initiation } \\
\text { stage }\end{array}$ & $3.49 \pm 1.55$ & $4(3-5)$ & $0-5$ & 3.34 & 3.64 & 0.08 & \multirow{3}{*}{0.60} \\
\hline & $\begin{array}{c}\text { Decision on } \\
\text { adopting innovation } \\
\text { stage }\end{array}$ & $3.78 \pm 1.21$ & $4(3-5)$ & $0-5$ & 3.66 & 3.90 & 0.06 & \\
\hline & $\begin{array}{c}\text { Innovation } \\
\text { implementation } \\
\text { stage }\end{array}$ & $3.73 \pm 1.23$ & $4(3-5)$ & $0-5$ & 3.60 & 3.85 & 0.06 & \\
\hline
\end{tabular}


Table A1. Cont.

\begin{tabular}{|c|c|c|c|c|c|c|c|c|}
\hline & & \multicolumn{6}{|c|}{ Descriptive Statistics } & \multirow{3}{*}{$\begin{array}{c}\text { Alfa } \\
\text { Cronbacha }\end{array}$} \\
\hline & & \multirow{2}{*}{$\begin{array}{c}\text { Average } \pm \\
\text { Standard Deviation }\end{array}$} & \multirow{2}{*}{$\begin{array}{l}\text { Median; } \\
\text { (Q25-Q75) }\end{array}$} & \multirow{2}{*}{ Min-Max } & \multicolumn{2}{|c|}{ Confidence Range } & \multirow{2}{*}{$\begin{array}{l}\text { Standard } \\
\text { Error }\end{array}$} & \\
\hline & & & & & $-95 \%$ & $+95 \%$ & & \\
\hline \multirow{3}{*}{$\begin{array}{c}\text { Regular } \\
\text { brainstorming }\end{array}$} & $\begin{array}{c}\text { Innovation initiation } \\
\text { stage }\end{array}$ & $4.18 \pm 1.06$ & $4(4-5)$ & $0-5$ & 4.08 & 4.28 & 0.05 & \multirow{3}{*}{0.63} \\
\hline & $\begin{array}{c}\text { Decision on } \\
\text { adopting innovation } \\
\text { stage }\end{array}$ & $4.02 \pm 1.08$ & $4(4-5)$ & $0-5$ & 3.91 & 4.12 & 0.05 & \\
\hline & $\begin{array}{c}\text { Innovation } \\
\text { implementation } \\
\text { stage }\end{array}$ & $3.51 \pm 1.49$ & $4(3-5)$ & $0-5$ & 3.36 & 3.65 & 0.07 & \\
\hline \multirow{3}{*}{$\begin{array}{l}\text { Openness to new } \\
\text { solutions and } \\
\text { flexibility in } \\
\text { solving problems }\end{array}$} & $\begin{array}{l}\text { Innovation initiation } \\
\text { stage }\end{array}$ & $4.21 \pm 1.13$ & $5(4-5)$ & $0-5$ & 4.10 & 4.32 & 0.06 & \multirow{3}{*}{0.85} \\
\hline & $\begin{array}{c}\text { Decision on } \\
\text { adopting innovation } \\
\text { stage }\end{array}$ & $4.21 \pm 0.98$ & $4(4-5)$ & $0-5$ & 4.11 & 4.30 & 0.05 & \\
\hline & $\begin{array}{l}\text { Innovation } \\
\text { implementation } \\
\text { stage }\end{array}$ & $4.15 \pm 1.05$ & $4(4-5)$ & $0-5$ & 4.04 & 4.25 & 0.05 & \\
\hline \multirow{3}{*}{$\begin{array}{l}\text { Mutual trust } \\
\text { within the } \\
\text { team/organisation }\end{array}$} & $\begin{array}{l}\text { Innovation initiation } \\
\text { stage }\end{array}$ & $3.31 \pm 1.84$ & $4(3-5)$ & $0-5$ & 3.13 & 3.49 & 0.09 & \multirow{3}{*}{0.69} \\
\hline & $\begin{array}{c}\text { Decision on } \\
\text { adopting innovation } \\
\text { stage }\end{array}$ & $3.89 \pm 1.29$ & $4(4-5)$ & $0-5$ & 3.76 & 4.02 & 0.06 & \\
\hline & $\begin{array}{c}\text { Innovation } \\
\text { implementation } \\
\text { stage }\end{array}$ & $4.13 \pm 1.2$ & $4(4-5)$ & $0-5$ & 4.01 & 4.25 & 0.06 & \\
\hline \multirow{3}{*}{$\begin{array}{l}\text { Proper recognition } \\
\text { and incentives for } \\
\text { employees }\end{array}$} & $\begin{array}{l}\text { Innovation initiation } \\
\text { stage }\end{array}$ & $4.22 \pm 1.09$ & $5(4-5)$ & $0-5$ & 4.12 & 4.33 & 0.05 & \multirow{3}{*}{0.90} \\
\hline & $\begin{array}{c}\text { Decision on } \\
\text { adopting innovation } \\
\text { stage }\end{array}$ & $4.17 \pm 1.16$ & $5(4-5)$ & $0-5$ & 4.06 & 4.28 & 0.06 & \\
\hline & $\begin{array}{c}\text { Innovation } \\
\text { implementation } \\
\text { stage }\end{array}$ & $4.22 \pm 1.12$ & $5(4-5)$ & $0-5$ & 4.11 & 4.33 & 0.06 & \\
\hline
\end{tabular}

Source: Authors' own work.

\section{References}

1. Schumpeter, J.A. Teoria Rozwoju Gospodarczego; PWN: Warsaw, Poland, 1960.

2. Kuzior, A.; Kwilinski, A.; Tkachenko, V. Sustainable development of organizations based on the combinatorial model of artificial intelligence. Entrep. Sustain. Issues 2019, 7, 1353-1376. [CrossRef]

3. Dosi, G. The nature of the innovative process. In Technical Change and Economic Theory; Dosi, G., Freeman, C., Nelson, R., Silverberg, G., Soete, L., Eds.; Printer: London, UK, 1988; pp. 221-238.

4. Caron-Fasan, M.-L.; Lesca, N.; Perea, C.; Beyrouthy, S. Adoption of enterprise social networking: Revisiting the IT innovation adoption model of Hameed et al. J. Eng. Technol. Manag. 2020, 56, 1-20. [CrossRef]

5. Dost, M.; Badir, Y.F.; Sambasivan, M.; Umrani, W.A. Open-and-closed process innovation generation and adoption: Analyzing the effects of sources of knowledge. Technol. Soc. 2020, 62, 1-8. [CrossRef]

6. von Oorschot, J.A.; Hofman, E.; Halman, J.I.M. A bibliometric review of the innovation adoption literature. Technol. Forecast. Soc. Chang. 2018, 134, 1-21. [CrossRef]

7. Styś, A.; Dejnaka, A. Innowacje w biznesie; Difin: Warsaw, Poland, 2018.

8. Szczepańska-Woszczyna, K. Kompetencje menedżerskie w kontekście innowacyjności przedsiębiorstwa; PWN: Warsaw, Poland, 2016.

9. Sopińska, A.; Mierzejewska, W. Otwarte innowacje produktowe realizowane przez przedsiębiorstwa działajace w Polsce; Oficyna Wydawnicza SGH: Warsaw, Poland, 2017.

10. Janasz, W.; Kozioł, K. Determinanty działalności innowacyjnej przedsiębiorstw; PWE: Warsaw, Poland, 2007.

11. Mielcarek, P. Doskonalenie procesów odnowy strategicznej i innowacji przedsiębiorstw; PWN: Warsaw, Poland, 2019.

12. Bielski, J. Przebieg i uwarunkowania procesów innowacyjnych; OPO: Bydgoszcz, Poland, 2000.

13. Romanowska, M. Determinanty innowacyjności polskich przedsiębiorstw. Przegląd Organizacji 2016, 2, $29-35$. [CrossRef]

14. Pyszka, A.; Bartoszewicz, M. Innowacyjność wymaga rutyny. Zastosowanie koncepcji design thinking w tworzeniu innowacji. Studia Ekonomiczne 2014, 183, 230-242. 
15. Sturges, J.; Conway, N.; Guest, D.; Liefooghe, A. Managing the career deal: The psychological contract as a framework for understanding career management, organizational commitment and work behavior. J. Organ. Behav. 2005, 26, 821-838. [CrossRef]

16. Anderson, P.; Tushman, M.L. Managing Through Cycles of Technological Change. Res. Technol. Manag. 1991, 34, 26-31. [CrossRef]

17. Damanpour, F. Organizational Innovation: A Meta-Analysis of Effects of Determinants and Moderators. Acad. Manag. J. 1991, 34, 555-590. [CrossRef]

18. Kimberly, J.R.; Evanisko, M.J. Organizational Innovation: The influence of individual, organizational, and contextual factors on hospital adoption of technological and administrative innovations. Acad. Manag. J. 1981, 24, 689-713. [CrossRef]

19. Damanpour, F.; Szabat, K.A.; Evan, W.N. The relationship between types of innovation and organizational performance. J. Manag. Stud. 1989, 26, 587-602. [CrossRef]

20. Nayyar, P.R. Stock market reactions to related diversification moves by service firms seeking benefits from information asymmetry and economies of scope. Strateg. Manag. J. 1993, 14, 569-591. [CrossRef]

21. Porter, M.E. Industry Structure and Competitive Strategy: Keys to Profitability. Financ. Anal. J. 1980, 36, 30-41. [CrossRef]

22. Utterback, J.M.; Abernathy, W.J. A dynamic model of process and product innovation. Omega 1975, 3, 639-656. [CrossRef]

23. Rogers, E.M. Diffusion of Innovations; Free Press: New York, NY, USA, 2003.

24. Mitchell, I. Innovation in non-food retailing in the early nineteenth century: The curious case of the bazaar. Bus. Hist. 2010, 52, 875-891. [CrossRef]

25. Dosi, G. Technological paradigms and technological trajectories: A suggested interpretation of the determinants and directions of technical change. Res. Policy 1982, 11, 147-162. [CrossRef]

26. Klein, B.; Crawford, R.G.; Alchian, A.A. Vertical Integration, Appropriable Rents, and the Competitive Contracting Process. J. Law Econ. 1978, 21, 297-326. [CrossRef]

27. Grossman, S.J.; Hart, O.D. The Costs and Benefits of Ownership: A Theory of Vertical and Lateral Integration. J. Polit. Econ. 1986, 94, 691-719. [CrossRef]

28. Harrigan, K.R. Matching vertical integration strategies to competitive conditions. Strateg. Manag. J. 1986, 7, 535-555. [CrossRef]

29. Malerba, F. Innovation, Industrial Dynamics and Industry Evolution: Progress and the Research Agendas. Revue de l'OFCE 2006, 97, 21-46. [CrossRef]

30. Balakrishnan, S.; Wernerfelt, B. Technical change, competition and vertical integration. Strateg. Manag. J. 1986, 7, 347-359. [CrossRef]

31. Monteverde, K.; Teece, D.J. Supplier Switching Costs and Vertical Integration in the Automobile Industry. Bell J. Econ. 1982, 13, 206-213. [CrossRef]

32. Gupta, A.; Toong, H.-M.D. Microcomputers in Industrial Control Applications. IEEE Trans. Ind. Electron. 1984, 31, 109-119. [CrossRef]

33. Teece, D.J. Profiting from technological innovation: Implications for integration, collaboration, licensing and public policy. Res. Policy 1986, 15, 285-305. [CrossRef]

34. Anderson, E.; Schmittlein, D.C. Integration of the Sales Force: An Empirical Examination. Rand J. Econ. 1984, 15, 385-395. [CrossRef]

35. Aaker, D.A. Managing the most important assets: Brand equity. Plan. Rev. 1992, 20, 56-58. [CrossRef]

36. Abernathy, W.J.; Clark, K.B. Innovation: Mapping the winds of creative destruction. Res. Policy 1985, 14, 3-22. [CrossRef]

37. Oster, G.; Alberch, P. Evolution and Bifurcation of Developmental Programs. Evolution 1982, 36, 444-459. [CrossRef]

38. Nadler, D.A.; Tushman, M.L. Competing by Design: The Power of Organizational Architecture; Oxford University Press: Oxford, UK, 1997. [CrossRef]

39. Hetzner, W.A.; Tornatzky, L.G.; Klein, K.J. Manufacturing Technology in the 1980's: A Survey of Federal Programs and Practices. Manag. Sci. 1983, 29, 951-961. [CrossRef]

40. Meyer, A.D.; Goes, J.B. Organizational Assimilation of Innovations: A Multilevel Contextual Analysis. Acad. Manag. J. 1988, 31, 897-923. [CrossRef] 
41. Baldridge, J.V.; Burnham, R.A. Organizational innovation: Individual, organizational, and environmental impacts. Adm. Sci. Q. 1975, 20, 165-176. [CrossRef]

42. Katz, M.L.; Shapiro, C. On the Licensing of Innovation. RAND J. Econ. 1985, 16, 504-520. [CrossRef]

43. Dougherty, D.; Hardy, C. Sustained Product Innovation in Large, Mature Organizations: Overcoming Innovation-to-Organization Problems. Acad. Manag. J. 1996, 39, 1120-1153. [CrossRef]

44. Mintzberg, H.; Hage, J. The Structuring of Organizations: A Synthesis of Research. Adm. Sci. Q. 1980, 25, 547-552. [CrossRef]

45. Tornatzky, L.G.; Klein, K.J. Innovation characteristics and innovation adoption-implementation: A meta-analysis of findings. IEEE Trans. Eng. Manag. 1982, EM-29, 28-45. [CrossRef]

46. Mansfield, E. Industrial Research and Technological Innovation: An Econometric Analysis. Econ. J. 1968, 78, 676-679. [CrossRef]

47. Von Hippel, E. Lead Users: A Source of Novel Product Concepts. Manag. Sci. 1986, 32, 773-907. [CrossRef]

48. Hoskisson, R.E.; Hitt, M.A.; Ireland, R.D. The Effects of Acquisitions and Restructuring (Strategic Refocusing) Strategies on Innovation. In The Management of Corporate Acquisitions; von Krogh, G., Sinatra, A., Singh, H., Eds.; Palgrave Macmillan: London, UK, 1994; pp. 144-169. [CrossRef]

49. Markides, C.C. The Economic Characteristics of De-diversifying Firms. Br. J. Manag. 1992, 3, 91-100. [CrossRef]

50. Miles, R.E.; Snow, C.C.; Miles, G. The ideology of innovation. Strateg. Organ. 2007, 5, 423-435. [CrossRef]

51. Crossan, M.M.; Apaydin, M. A Multi-Dimensional Framework of Organizational Innovation: A Systematic Review of the Literature. J. Manag. Stud. 2010, 47, 1154-1191. [CrossRef]

52. Walker, R.M.; Damanpour, F.; Devece, C.A. Management Innovation and Organizational Performance: The Mediating Effect of Performance Management. J. Public Adm. Res. Theory 2011, 21, 367-386. [CrossRef]

53. Mol, M.J.; Birkinshaw, J. The Sources of Management Innovation: When Firms Introduce New Management Practices. J. Bus. Res. 2009, 62, 1269-1280. [CrossRef]

54. Vaccaro, I.G.; Jansen, J.J.P.; Bosch, F.A.J.; Volberda, H.W. Management Innovation and Leadership: The Moderating Role of Organizational Size. J. Manag. Stud. 2012, 49, 28-51. [CrossRef]

55. Azar, G.; Ciabuschi, F. Organizational innovation, technological innovation, and export performance: The effects of innovation radicalness and extensiveness. Int. Bus. Rev. 2017, 26, 324-336. [CrossRef]

56. Hansen, E.G. Responsible Leadership Systems; Gabler: Wiesbaden, Deutschland, 2010. [CrossRef]

57. Nieves, J. Outcomes of Management Innovation: An Empirical Analysis in the Services Industry. Eur. Manag. Rev. 2016, 13, 125-136. [CrossRef]

58. Zhou, M.; Vaccaro, L.C.; Qi, W. The Impact of Internationalization on Organizational Innovation. In Proceedings of the 2010 3rd International Conference on Information Management, Innovation Management and Industrial Engineering, Kunming, China, 26-28 November 2010; IEEE: Piscataway, NJ, USA, 2010. [CrossRef]

59. Černe, M.; Jaklič, M.; Škerlavaj, M. Authentic leadership, creativity, and innovation: A multilevel perspective. Leadership 2013, 9, 63-85. [CrossRef]

60. Iansiti, M. Technology integration: Managing technological evolution in a complex environment. Res. Policy 1995, 24, 521-542. [CrossRef]

61. Kogut, B.; Zander, U. Knowledge of the Firm, Combinative Capabilities, and the Replication of Technology. Organ. Sci. 1992, 3, 383-397. [CrossRef]

62. Khosravi, P.; Newton, C.; Rezvani, A. Management innovation: A systematic review and meta-analysis of past decades of research. Eur. Manag. J. 2019, 37, 694-707. [CrossRef]

63. Sears, G.J.; Baba, V.V. Toward a Multistage, Multilevel Theory of Innovation. Can. J. Adm. Sci. 2011, 28, 357-372. [CrossRef]

64. Damanpour, F.; Aravind, D. Managerial Innovation: Conceptions, Processes and Antecedents. Manag. Organ. Rev. 2012, 8, 423-454. [CrossRef]

65. Birkinshaw, J.; Hamel, G.; Mol, M.J. Management Innovation. Acad. Manag. Rev. 2008, 33, 825-845. [CrossRef]

66. Kraus, S.; Pohjola, M.; Koponen, A. Innovation in family firms: An empirical analysis linking organizational and managerial innovation to corporate success. Rev. Manag. Sci. 2012, 6, 265-286. [CrossRef]

67. Yam, R.C.M.; Lo, W.; Tang, E.P.Y.; Lau, A.K.W. Analysis of sources of innovation, technological innovation capabilities, and performance: An empirical study of Hong Kong manufacturing industries. Res. Policy 2011, 40, 391-402. [CrossRef] 
68. Hansen, M.T.; Birkinshaw, J. Want to Improve Innovation? Tailor Your Solution, Don't Import Best Innovation Practices. INSEAD Bus. Sch. Res. Pap. 2007, 10, 1-23. [CrossRef]

69. Pisano, G.P.; Teece, D.J. How to Capture Value from Innovation: Shaping Intellectual Property and Industry Architecture. Calif. Manag. Rev. 2007, 50, 278-296. [CrossRef]

70. Camisón, C.; Villar-López, A. Organizational innovation as an enabler of technological innovation capabilities and firm performance. J. Bus. Res. 2014, 67, 2891-2902. [CrossRef]

71. Chiu, C.-N.; Yang, C.-L. Competitive advantage and simultaneous mutual influences between information technology adoption and service innovation: Moderating effects of environmental factors. Struct. Chang. Econ. Dyn. 2019, 49, 192-205. [CrossRef]

72. Kochmańska, A. Innovative approach to the management of culturally diverse human resources in today's labour market. Sil. Univ. Technol. Sci. Pap. Organ. Manag. 2019, 141, 173-182. [CrossRef]

73. Wolniak, R.; Grebski, M.E.; Skotnicka-Zasadzien, B. Comparative analysis of the level of satisfaction with the services received at the business incubators (Hazleton, PA, USA and Gliwice, Poland). Sustainability 2019, 11, 2889. [CrossRef]

74. Nam, D.; Lee, J.; Lee, H. Business analytics adoption process: An innovation diffusion perspective. Int. J. Inf. Manag. 2019, 49, 411-423. [CrossRef]

75. Bankole, F.O.; Bankole, O.O. The effects of cultural dimension on ICT innovation: Empirical analysis of mobile phone services. Telemat. Inform. 2017, 34, 490-505. [CrossRef]

76. Hameed, M.A.; Counsell, S.; Swift, S. A conceptual model for the process of IT innovation adoption in organizations. J. Eng. Technol. Manag. 2012, 29, 358-390. [CrossRef]

77. Bolek, C.; Bolek, M. Komercjalizacja Innowacji: Zarzadzanie Projektami i Finansowanie; Difin: Warsaw, Poland, 2014.

78. Talukder, M. Managing Innovation Adoption. From Innovation to Implementation; Routledge: New York, NY, USA, 2016.

79. Gruenhagen, J.H.; Parker, R. Factors driving or impeding the diffusion and adoption of innovation in mining: A systematic review of the literature. Resour. Policy 2020, 65, 1-9. [CrossRef]

80. Sun, S.; Lee, P.C.; Law, R.; Zhong, L. The impact of cultural values on the acceptance of hotel technology adoption from the perspective of hotel employees. J. Hosp. Tour. Manag. 2020, 44, 61-69. [CrossRef]

81. Alofan, F.; Chen, S.; Tan, H. National cultural distance, organizational culture, and adaptation of management innovations in foreign subsidiaries: A fuzzy set analysis of TQM implementation in Saudi Arabia. J. Bus. Res. 2020, 109, 184-199. [CrossRef]

82. Zbiegień- Maciąg, L. Kultura w Organizacji. Identyfikacja Kultur Znanych Firm; PWN: Warsaw, Poland, 2013.

83. Sułkowski, Ł. Kulturowa Zmienność Organizacji; PWE: Warsaw, Poland, 2002.

84. Łaguna, M.; Purc, E.; Razmus, W.; Błaszczyk, M.; Gawrońska, K. Podejmowanie szkoleń a kultura i klimat organizacyjny. Organizacja i Kierowanie 2015, 2, 141-154.

85. Mullins, L.J. Management and Organizational Behaviour; Pearson Education Limited: Harlow, UK, 2005.

86. Gęca, B. Kultura ryzyka jako system zachowań i wartości obecnych worganizacji zorientowanych na ryzyko. In Przedsiębiorczość i Zarzadzanie w Gospodarce Opartej na Wiedzy; Mieszajkina, E., Ed.; Wyższa Szkoła Przedsiębiorczości i Administracji w Lublinie: Lublin, Poland, 2014; pp. 1-10. [CrossRef]

87. Sasin, M. Kształtowanie Kultury Organizacyjnej w Praktyce; Akademia Rozwoju Kompetencji: Dąbrówka, Poland, 2017.

88. Płatek, W. Jak Generować Pomysły? Burza Mózgów, Dyskusja 66 i Inne Metody Rozwiazzywania Problemów; ICAN Management Review. Available online: https://www.hbrp.pl/b/jak-generowac-pomysly-burzamozgow-dyskusja-66-i-inne-metody-rozwiazywania-problemow/P18JJT3QnR (accessed on 3 April 2020).

89. Mazur, M. Motywowanie pracowników jako istotny element zarządzania organizacją. Nauki Społeczne 2013, 2, 156-182.

90. Bulińska-Stangrecka, H. Konceptualizacja e-kultury. Zarządzanie kulturą organizacji w warunkach ryzyka. Studia Ekonomiczne 2015, 222, 101-115.

91. Pichlak, M. Uwarunkowania procesu adaptacji innowacji w polskich organizacjach. Organizacja $i$ kierowanie 2015, 2, 37-50.

92. Reaktor. Rynek IT w Polsce. Available online: https://reaktor.pwn.pl/rynek-it-polsce/ (accessed on 12 July 2020).

93. Czakon, W. Podstawy Metodologii Badań w Naukach o Zarzadzaniu; Wydawnictwo Nieoczywiste: Piaseczno, Poland, 2016. 
94. Kostera, M. Antropologia Organizacji. Metodologia Badań Terenowych; PWN: Warsaw, Poland, 2003.

95. Dźwigoł, H. Wspótczesne Procesy Badawcze w Naukach o Zarządzaniu. Uwarunkowania Metodyczne $i$ Metodologiczne; PWN: Warsaw, Poland, 2018.

96. Stanisz, A. Przystepny Kurs Statystyki z Zastosowaniem STATISTICA PL na Przykładach z Medycyny. Tom 3. Analizy wielowymiarowe; StatSoft Polska Sp. z o.o.: Cracow, Poland, 2007.

97. Stanisz, A. Przystępny Kurs Statystyki z Zastosowaniem STATISTICA PL na Przykładach z Medycyny. Tom 1. Statystyki Podstawowe; StatSoft Polska Sp. z o.o.: Cracow, Poland, 2006.

98. Panczyk, M. Prezentacja Podstawy Biostatystyki 9a. Miary Wielkości Efektu. Available online: https://www.authorstream.com/Presentation/panstudio-2620824-9a-miary-wielko-ci-efektu-dla-por-wnadw-ch-grup/ (accessed on 11 August 2019).

99. Mynarski, S. Praktyczne Metody Analizy Danych Rynkowych i Marketingowych; Kantor Wydawniczy Zakamycze: Cracow, Poland, 2000.

100. Number of Employees in the IT Industry in Poland in 2017 (as of November 2018) Based on the Central Statistical Office (GUS) According to the Code pkd62 "Services Related to Software and Consulting in the Field of IT and Related Services" (Only Companies Declaring Employment of 10 People or More Were Taken into Account). Available online: http://stat.gov.pl/obszary-tematyczne/rynek-pracy/pracujacy-zatrudnieniwynagrodzenia-koszty-pracy/pracujacy-w-gospodarce-narodowej-w-2017-roku,7,15.html (accessed on 25 November 2018).

101. Number of IT Companies in Poland in 2018 (as of November 2018) Based on the Central Statistical Office (GUS) According to the Code pkd62 “Services Related to Software and IT Consulting and Related Services" (Only Companies Declaring Employment of 10 People or More Were Taken into Account). Available online: https://stat.gov.pl/obszary-tematyczne/podmioty-gospodarcze-wyniki-finansowe/zmianystrukturalne-grup-podmiotow/miesieczna-informacja-o-podmiotach-gospodarki-narodowej-w-rejestrzeregon-pazdziernik-2018,4,16.html (accessed on 25 November 2018).

Publisher's Note: MDPI stays neutral with regard to jurisdictional claims in published maps and institutional affiliations.

(C) 2020 by the author. Licensee MDPI, Basel, Switzerland. This article is an open access article distributed under the terms and conditions of the Creative Commons Attribution (CC BY) license (http://creativecommons.org/licenses/by/4.0/). 